\title{
The phytoplankton biodiversity of the coast of the state of São Paulo, Brazil
}

\author{
Maria Célia Villac ${ }^{1,2}$, Valéria Aparecida de Paula Cabral-Noronha ${ }^{1} \&$ Thatiana de Oliveira Pinto ${ }^{1}$ \\ ${ }^{1}$ Departamento de Biologia, Universidade de Taubaté - UNITAU, \\ Av. Tiradentes, 500, CEP12030-180, Taubaté, SP, Brazil \\ ${ }^{2}$ Corresponding author: Maria Célia Villac,e-mail: celiavillac@gmail.com
}

\begin{abstract}
VILLAC, M.C., CABRAL-NORONHA, V.A.P. \& PINTO, T.O. 2008. The phytoplankton biodiversity of the coast of the state of São Paulo, Brazil. Biota Neotrop. 8(3): http://www.biotaneotropica.org.br/v8n3/en/ abstract?article+bn01908032008.
\end{abstract}

\begin{abstract}
The objective of this study is to compile the inventory of nearly 100 years of research about the phytoplankton species cited for the coast of the state of São Paulo, Brazil. A state-of-the-art study on the local biodiversity has long been needed to provide a baseline for future comparisons. This type of data is scattered in old scientific journals and in the so-called "grey literature", and are in need of nomenclature updating. Twentysix publications are considered. The earliest sampling record is from 1913 (?) and the most recent from 2002. This checklist compiled from the literature was complemented with primary data collected between August 2004 and July 2006, recent surveys of the surf-zone of 20 beaches located along the coast and of a mariculture farm at the Cocanha Beach, Caraguatatuba. The complete species list includes 572 taxa: most are diatoms (82\%), seconded by dinoflagellates (16\%), with a minor contribution of silicoflagellates, coccolithophorids, ebriideans and cyanobacteria. The most investigated areas were: Ubatuba, São Sebastião, Santos and Cananéia. The recent surveys have a broader spatial coverage. The objectives of the studies have changed over the years from purely taxonomic to process-oriented investigations. Therefore, the longest species lists and most first records for the area were published before the 1980's and later publications, even those in which cell counts were performed, mention only the most abundant/frequent species. Electron microscopy was used for the first time in the present surveys, and new records include 38 diatoms, 42 dinoflagellates, 1 silicoflagellate, 1 ebriidean and 2 cyanobacteria. The use and interpretation of this species list require the perception of some constraints. It is not our role to question the identification made by other researchers. On the other hand, the ability to sample, analyze and identify species has evolved over the years and some considerations in this regard are presented.
\end{abstract}

Keywords: marine microalgae, inventory, diatoms, dinoflagellates.

VILLAC, M.C., CABRAL-NORONHA, V.A.P. \& PINTO, T.O. 2008. A biodiversidade do fitoplâncton do litoral do estado de São Paulo, Brasil. Biota Neotrop. 8(3): http://www.biotaneotropica.org.br/v8n3/pt/ abstract?article+bn01908032008.

Resumo: O objetivo deste estudo é compilar o inventário de quase 100 anos de pesquisa sobre a composição de espécies do fitoplâncton do litoral do Estado de São Paulo, Brasil. O retrato atualizado da biodiversidade local é necessário para establecer um dignóstico para comparações futuras. Este tipo de informação encontra-se dispersa em antigas publicações e em material considerado como "literatura cinza" e requer atualização nomenclatural. Vinte e seis publicações foram consideradas neste estudo. O registro mais antigo é de 1913 (?) e o mais recente de 2002. Esta lista de espécies, compilada a partir de dados pretéritos, foi complementada com dados primários coletados entre agosto de 2004 e julho de 2006 nas zonas de arrebentação de 20 praias paulistas e em área de maricultura da praia da Cocanha em Caraguatatuba. A lista de espécies completa inclui 572 táxons: a maioria de diatomáceas (82\%), seguidas por dinoflagelados (16\%), com uma pequena contribuição de silicoflagelados, cocolitoforídeos, ebriideas e cianobactérias. As áreas mais estudadas foram: Ubatuba, São Sebastião, Santos e Cananéia. O levantamento atual tem uma cobertura espacial mais abrangente. Ao longo dos anos, os objetivos dos estudos pretéritos variaram desde puramente taxonômicos até investigações de aspectos funcionais do ecossistema. Desta forma, os inventários mais longos e a maioria dos primeiros registros foram publicados antes de 1980 e as publicações mais recentes fazem menção apenas a espécies mais abundantes/freqüentes. Microscopia eletrônica foi empregada pela primeira vez no levantamento atual e novos registros incluem 38 diatomáceas, 42 dinoflagelados, 1 silicoflagelado, 1 ebriidea e 2 cianobactérias. O uso e interpretação deste inventário exige cautela. Se por um lado, não é viável questionar a identificação feita por outros pesquisadores, por outro lado, a capacidade de amostrar, analisar e identificar espécies evoluiu ao longo do tempo. Algumas considerações sobre esta questão são apresentadas.

Palavras-chave: microalgas marinhas, inventário, diatomáceas, dinoflagelados. 


\section{Introduction}

Phytoplankton studies include a variety of taxonomic groups (cyanobacteria, diatoms, dinoflagellates, silicoflagelates, coccolithophorids, and many other flagellates) that inhabit the water column. This is an artificial category, that is, the organisms are not phylogenetically related (Adl et al. 2005). Although these organisms are regarded as unicellular microalgae and most of them are indeed autotrophs, several species or even whole genera (e.g., the dinoflagellates Protoperidinium Bergh) are known to be heterotrophs (Steidinger \& Tangen 1997). An extreme case is that of the ebriideans, Ebria tripartita (Schumann) Lemmermann and Hermesinum adriaticum Zacharias, which actually belong to the Phylum Sarcomastigophora (according to Lee et al. 1985 in Throndsen 1997); they are traditionally considered in phytoplankton counts mostly because their taxonomic status has changed over the years to be considered silicoflagellates (Drebes 1974) or dinoflagellates (Sournia 1986).

According to Sournia et al. (1991), marine phytoplankton of the world may include as many as 17 classes and an estimated number of $498 \pm 15$ genera and 3,910 \pm 465 species. The authors recognize that taxonomy is a dynamic science and that these numbers were probably already underestimated at the time of their publication. A more recent source of change in our perception of biodiversity, especially in the protistan realm, is due to the introduction of immunochemical and molecular biological methods that can reveal intra- and infraspecific variations that went unnoticed before.

The objective of this study is to compile and make available the inventory of the phytoplankton species cited for the coast of the state of São Paulo, Brazil. As will be demonstrated, there is almost 100 years of research in the area, but this type of data (species lists) is scattered and in need of nomenclature updating. A state-of-the-art assessment of the biodiversity of the local phytoplankton is long needed to provide a baseline for future comparisons.

\section{Material and Methods}

This assessment was based on published information available in scientific journals as well as in the so-called "grey literature" (technical reports, academic thesis and dissertation, expanded abstracts from scientific events) for the coast of São Paulo. For this data set, the earliest sampling year is 1913 (?) and the most recent record reports on samples collected in 2002. The objectives, field and laboratory methods used in these surveys are summarized in Table 1 and will be discussed further below. The publications of Zimmerman, dated from 1913 to 1918 , were combined as a sole record because there is no reference for sampling dates and, at times, the same article is published in two different issues.

This species checklist compiled from the literature was complemented with primary data collected between August 2004 and July 2006, using data from 2 different sampling schemes. Phytoplankton samples were taken monthly from the surf-zone of 20 beaches located along the coast (Figure 1). Theses samples were taken almost simultaneously (within 24 hours) by surface net hauls ( $20 \mu \mathrm{m}$-mesh). From June 2005 to May 2006, sampling was also carried out at the mussel mariculture located at the Cocanha Beach, in Caraguatatuba. In this case, vertical net hauls (from $3 \mathrm{~m}$ depth to surface, same mesh size) were taken monthly at 5 sites (insert of Figure 1). All samples were initially analyzed with the aid of the Utermöhl's settling chambers using a Nikon TS100 inverted microscope equipped with phase contrast. Specific methods for finer taxonomic study were applied for observation in light microscopy (LM, Olympus BX41 equipped with phase contrast and epifluorescence) and also scanning electron microscopy (SEM, LEO 1450VP Zeiss). For diatoms, it was necessary to clean the cells from the organic matter that obscures the structures of the frustules; for LM, permanent slides were prepared with a medium of high refractive index (Naphrax), whereas for SEM a drop of the cleaned material was air-dried on a cover slip that was then sputtered with gold (Hasle \& Fryxell 1970). For armored dinoflagellates, observation of plate patterns in LM were done on wet mounts with the use of hypochlorite to separate plates and/or by the addition of the fluorochrome Calcofluor white (Fritz \& Triemer 1985, Boltovskoy 1995); SEM study of the more resistant species was also possible. A few unarmored species were identified from live samples. This is still an ongoing research and the species list presented here should be considered as preliminary.

The complete species list is found in the Appendix. Nomenclature was updated to the best of our ability, based on a vast literature and the algae database provided by Guiry \& Guiry (2008). The correct names of many taxa should still be regarded under scrutiny, as marked directly on the species list, either because we were unable to locate the validity of the name or the taxonomic status of a genus/species was considered unresolved, as will be illustrated further below. This difficulty is not unexpected, considering that some records are almost 100 years old and collections are not available to verify diagnostic characters. Synonyms were included, although restricted to citations found in the publications considered in this assessment. These shortcomings led to the choice of not adopting a classification system at present and the species list was thus organized in alphabetical order.

The publication of Oliveira (1980) was not taken into account because it dealt with epiphytic diatoms on Sargassum, although we do recognize that some species may be shaken off the thallus of the seaweed and can be, at times, detected in the water column. A wealth of publications that focused mostly on primary production and/or pigment concentrations are key to understand phytoplankton dynamics in the study area (e.g., Galvão 1978, Gaeta et al. 1990, Aidar et al. 1993, Gaeta et al. 1995, Lima 1998, Gaeta et al. 1999, Saldanha-Correa \& Gianesella 2004, Barrera-Alba et al. 2008), but they were not included in this account because they did not provide information at the species level.

\section{Results and Discussion}

\section{The species list in a historical perspective}

Phytoplankton studies from the coast of the state of São Paulo date back to 1913 (Zimmerman, 1913). Twenty-six publications are considered in this assessment (Table 1). The species list includes 572 taxa (Appendix). The great majority of the species found are diatoms $(82 \%)$, seconded by dinoflagellates $(16 \%)$, and a minor contribution of silicoflagellates, coccolithophorids, ebriideans and cyanobacteria was also reported (Table 2). The most investigated areas were, from north to south: Ubatuba, São Sebastião, Santos and Cananéia (refer to Table 1 and names of municipalities on Figure 1). The recent surveys have a broader spatial coverage (refer to Figure 1)

The objectives of the published studies have changed over the years from purely taxonomic studies to process-oriented investigations. Therefore, the longest species lists and most first records for the area are published in the studies carried out before the 1980's (Figure 2) and later publications, even those in which cell counts were performed, mention only the most abundant/frequent species. New records for the coast of São Paulo state (present study: 2004-2006) includes 38 diatoms, 42 dinoflagellates, 1 silicoflagellate, 1 ebriidean and 2 cyanobacteria (Appendix).

The larger contribution of diatoms and dinoflagellates is expected and is in accordance with the review of Sournia et al. (1991) that 


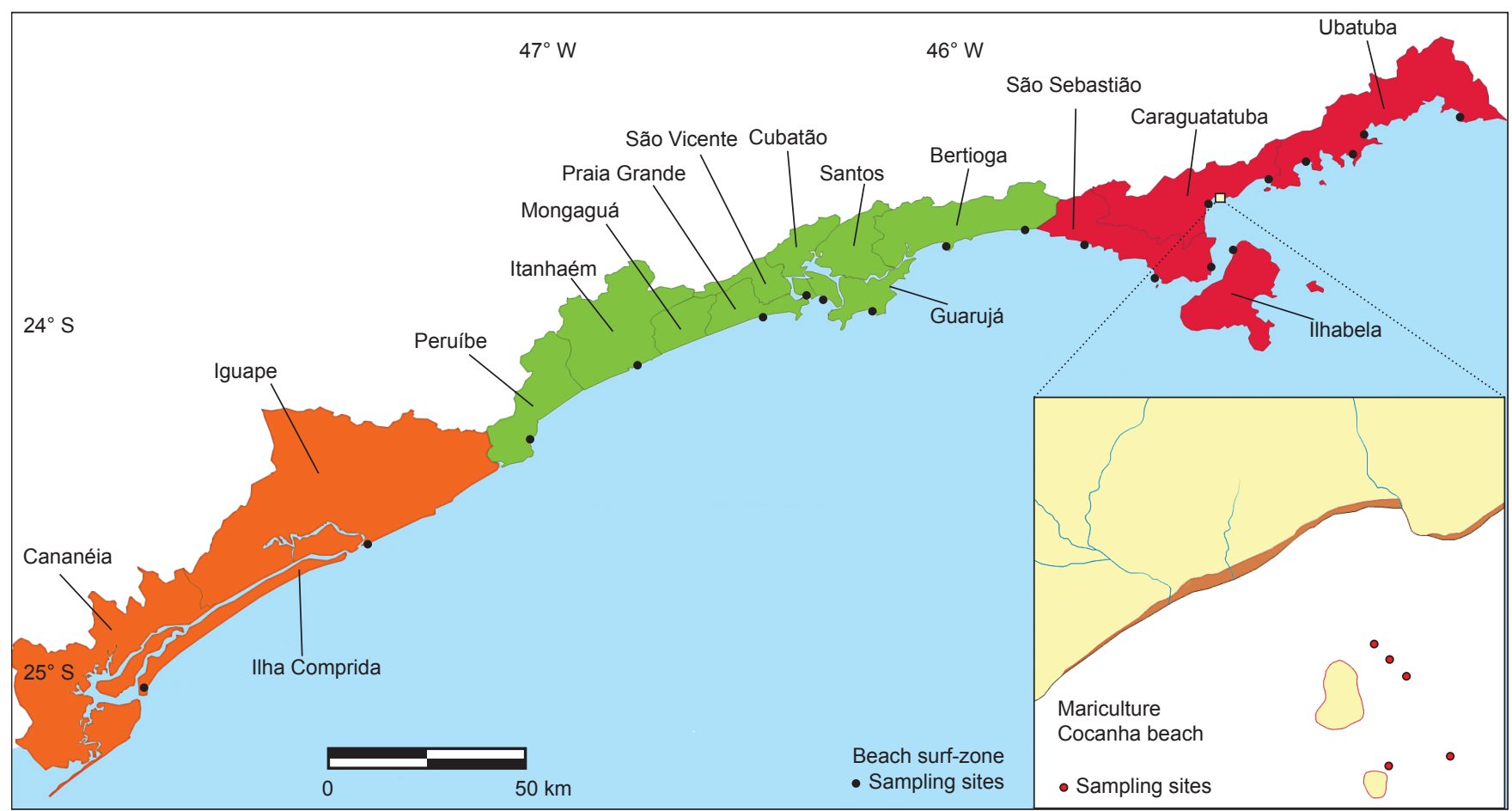

Figure 1. The coastline of the state of São Paulo, including the names of the 16 coastal municipalities, as well as the locations of the sampling sites visited during August/2004 and July/2006 (primary data).

Figura 1. Litoral do Estado de São Paulo, incluindo os nomes das 16 cidades costeiras e os locais dos pontos de coleta visitados no período entre agosto/2004 e julho/2006 (dados primários).

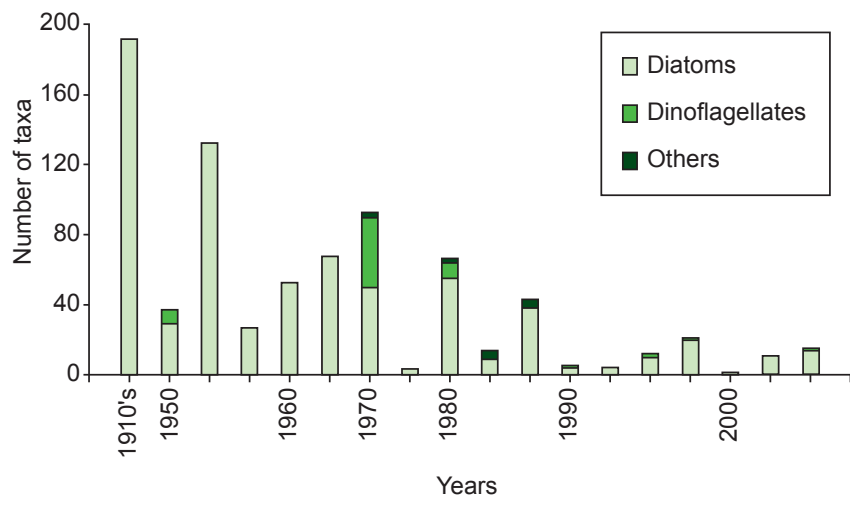

Figure 2. Relative contribution of the number of species of marine microalgae found in the studies published between 1913 and 2002 (listed in Table 1).

Figura 2. Contribuição relative do número de espécies de microalgas encontradas nos estudos publicados entre 1913 e 2002 (listados na Tabela 1).

estimates numbers of species for the marine phytoplankton: diatoms (1365-1783), dinoflagellates (1424-1772), coccolithophorids (239-298), chlorophytes (106-121), prasinophytes (95-128), cryptophytes (56-73), euglenophytes (35-36), silicoflagellates (1-3), cyanobacteria (6-9), among others. Brazil (and the state of São Paulo) has a stronger tradition of diatomists, which explains our greater knowledge of diatom species composition (Figure 3). For the state of São Paulo, only the study of Sassi (1978) and the recent surveys made a special effort to augment our understanding of dinoflagellate species composition (Table 2; Figure 3). As a general rule, the identification of

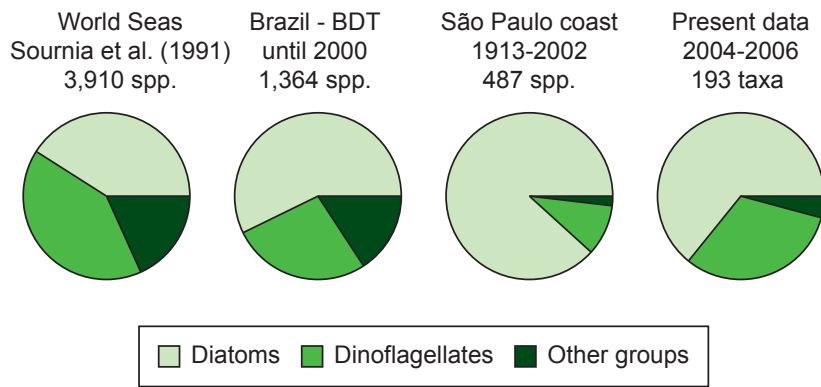

Figure 3. Relative contribution of the main taxonomic groups at different levels: worldwide (Sournia et al. 1991), Brazil (Banco de Dados Tropical - www. bdt.fat.org.br/workshop/costa), pre-existing data for the state of São Paulo (references in Table 1), and primary data for the state of São Paulo.

Figura 3. Contribuição relativa dos principais grupos taxonômicos em diferentes níveis: distribuição mundial (Sournia et al. 1991), no Brazil (Bando de Dados Tropical - www.bdt.fat.org.br/workshop/costa), dados pretéritos para o Estado de São Paulo (referências na Tabela 1) e dados primários para o Estado de São Paulo.

flagellates, including naked dinoflagellates, requires the study of live samples and/or electron microscopy, which is not routinely possible in many laboratories. We are still a long ways from grasping the true biodiversity of such taxonomic groups in Brazilian waters.

The most frequently cited species are listed in Table 3 and they are all diatoms commonly found in coastal waters (Hasle \& Syvertsen 1997). Except for Phaeodactylum tricornutum Bohlin, Pseudo-nitzschia Hassal and Skeletonema costatum Greville, whose taxonomy will be discussed further below, the other 26 species can be readily identified in wet mounts with light microscopy. 
Table 1. List of publications that cite the occurrence of microalgae species for the coast of the state of São Paulo, organized by sampling date and indicating locality, sampling period, approach of the study, and methods used. Locality includes the name of the municipality that can be located on Figure 1. Each reference is given a code that is referred to in other figures and tables. Publications by Zimmermann are combined as one record (Z).

Tabela 1. Lista de publicações que citam a ocorrência de espécies de microalgas para o litoral do Estado de São Paulo, organizada segundo a data de coleta e indicando local e período de coleta, abordagem do estudo e métodos utilizados. Local de coleta inclui nome da cidade que pode ser localizada na Figura 1. Cada referência recebeu um código que é utilizado em outras figuras e tabelas. As publicações de Zimmermann foram reunidas de modo a corresponder a um único registro (código Z).

\begin{tabular}{|c|c|c|c|c|c|c|c|}
\hline $\begin{array}{l}\text { Sampling } \\
\text { year }\end{array}$ & Locality & Period & Approach & Field work & Type of analysis & Reference & Code \\
\hline 1913-1918? & $\begin{array}{l}\text { Guarujá \& } \\
\text { Santos }\end{array}$ & $?$ & species composition & $?$ & $?$ & $\begin{array}{c}\text { Zimmermann } \\
(1913,1914, \\
1915 a, b, 1916 a, b, \\
1917,1918 a, b)\end{array}$ & $\mathrm{Z}$ \\
\hline 1949 & $\begin{array}{l}\text { River Maria } \\
\text { Rodrigues, } \\
\text { Cananéia }\end{array}$ & $\begin{array}{l}7 \text { June - } 20 \\
\text { October }\end{array}$ & species composition & $\begin{array}{l}\text { surface tow, net of } \\
\text { No00 mesh (?) }\end{array}$ & $\begin{array}{l}\text { qualitative, no } \\
\text { details provided }\end{array}$ & $\begin{array}{c}\text { Carvalho } \\
(1950)\end{array}$ & 1 \\
\hline 1949-1950 & $\begin{array}{l}\text { São } \\
\text { Sebastião, } \\
\text { Santos, } \\
\text { Cananéia }\end{array}$ & $\begin{array}{l}10 \text { samples } \\
\text { provided by } \\
\text { J. Paiva } \\
\text { Carvalho }\end{array}$ & species composition & net? & $\begin{array}{l}\text { observation of } \\
\text { wet mounts and } \\
\text { diatom permanent } \\
\text { mounts }\end{array}$ & $\begin{array}{l}\text { Müller-Melchers } \\
\text { (1955) }\end{array}$ & 2 \\
\hline $1957 ?$ & $\begin{array}{l}\text { Ubatuba, } \\
\text { Cananéia }\end{array}$ & $?$ & species composition & $\begin{array}{l}\text { - net, surface haul; } \\
\text { - seaweed, picked } \\
\text { manually; } \\
\text { - stomach content } \\
\text { (fish); } \\
\text { - sediment }\end{array}$ & $\begin{array}{l}\text { diatom } \\
\text { permanent } \\
\text { mounts }\end{array}$ & $\begin{array}{l}\text { Andrade \& Teix- } \\
\quad \text { eira (1957) }\end{array}$ & 3 \\
\hline 1968 & Cananéia & $\begin{array}{c}\text { 2-3 February } \\
\text { 17-18 July }\end{array}$ & $\begin{array}{l}\text { primary production } \\
\text { with species list }\end{array}$ & $\begin{array}{l}\text { bottle (?); } \\
\text { surface \& bottom }\end{array}$ & $?$ & $\begin{array}{l}\text { Teixeira } \\
(1969)\end{array}$ & 4 \\
\hline 1969-1970 & Cananéia & $\begin{array}{l}\text { December- } \\
\text { October } \\
\text { every other } \\
\text { month }\end{array}$ & $\begin{array}{l}\text { space-time } \\
\text { distribution in } \\
\text { species composition } \\
\& \text { abundance }\end{array}$ & $\begin{array}{l}5 \text { sites along the } \\
\text { estuarine gradient; } \\
\text { Nansen bottle; } \\
\text { surface and at } 1 \% \\
\text { light; some of the } \\
\text { material concentrat- } \\
\text { ed in } 30 \mu \mathrm{m} \text { mesh }\end{array}$ & $\begin{array}{l}\text { Utermöhl's } \\
\text { settling } \\
\text { technique for } \\
\text { bottle samples } \\
\text { and Sedwick- } \\
\text { Rafter for net } \\
\text { samples }\end{array}$ & $\begin{array}{l}\text { Kutner } \\
(1972)\end{array}$ & 5 \\
\hline $1974 / 1975$ & $\begin{array}{l}\text { Saco da } \\
\text { Ribeira, } \\
\text { Ubatuba }\end{array}$ & $\begin{array}{l}\text { June- } \\
\text { September } \\
\text { monthly }\end{array}$ & $\begin{array}{l}\text { space-time } \\
\text { distribution in } \\
\text { species } \\
\text { composition \& } \\
\text { abundance }\end{array}$ & $\begin{array}{l}1 \text { site; surface, } \\
\text { Secchi and bottom; } \\
\text { Van Dorn bottle; } \\
\text { surface tow with net } \\
\text { of } 65 \mu \mathrm{m} \text { mesh }\end{array}$ & $\begin{array}{l}\text { Utermöhl's } \\
\text { settling technique } \\
\text { (bottle samples } \\
\text { in cells per liter, } \\
\text { net samples in } \\
\text { percentage) }\end{array}$ & $\begin{array}{l}\text { Sassi } \\
(1978)\end{array}$ & 6 \\
\hline 1977-1978 & Cananéia & $\begin{array}{l}\text { Aug/77 } \\
\text { Nov/77 } \\
\text { Feb/78 } \\
\text { May/78 }\end{array}$ & $\begin{array}{l}\text { diel variation } \\
\text { of ecological } \\
\text { parameters }\end{array}$ & $\begin{array}{l}1 \text { site; } 13 \text { con- } \\
\text { secutive samplings } \\
\text { within a 24-hour } \\
\text { period during spring } \\
\text { tides; surface \& 9m; } \\
\text { Nansen and Van } \\
\text { Dorn bottles }\end{array}$ & $\begin{array}{l}\text { Utermöhl's } \\
\text { settling } \\
\text { technique }\end{array}$ & $\begin{array}{l}\text { Brandini } \\
\text { (1982) }\end{array}$ & 7 \\
\hline $1982-1983$ & $\begin{array}{l}\text { River Una } \\
\text { do Prelado, } \\
\text { Juréia }\end{array}$ & $\begin{array}{l}\text { August-July } \\
\text { monthly } \\
\text { ebb \& } \\
\text { flood tides }\end{array}$ & $\begin{array}{l}\text { space-time } \\
\text { distribution in } \\
\text { species composition } \\
\text { \& abundance }\end{array}$ & $\begin{array}{l}6 \text { sites along the } \\
\text { estuarine gradient; } \\
\text { surface and bottom; } \\
\text { Van Dorn bottle; } \\
\text { surface tows with } \\
\text { net of } 45 \mu \mathrm{m}\end{array}$ & $\begin{array}{l}\text { Utermöhl's } \\
\text { settling technique } \\
\text { for bottle } \\
\text { samples; common } \\
\text { species from } \\
\text { net samples in } \\
\text { microscope slides }\end{array}$ & $\begin{array}{c}\text { Oliveira } \\
(1988)\end{array}$ & 8 \\
\hline 1985-1988 & $\begin{array}{l}\text { Between } \\
\text { Island } \\
\text { Anchieta \& } \\
\text { Island Vitória, } \\
\text { Ubatuba }\end{array}$ & $\begin{array}{l}4 \text { cruises } \\
\text { Oct/85, } \\
\text { Jan/86, } \\
\text { Jul/86, } \\
\text { Apr/88 }\end{array}$ & $\begin{array}{l}\text { space-time } \\
\text { distribution in } \\
\text { species composition } \\
\& \text { abundance }\end{array}$ & $\begin{array}{l}6 \text { sites; surface, } 10 \\
\text { m, } 20 \text { m and } 30 \text { m; } \\
\text { Niskin bottle }\end{array}$ & $\begin{array}{l}\text { Utermöhl's } \\
\text { settling } \\
\text { technique }\end{array}$ & $\begin{array}{l}\text { Zillmann } \\
\text { (1990) }\end{array}$ & 9 \\
\hline
\end{tabular}


Table 1. Continued...

\begin{tabular}{|c|c|c|c|c|c|c|c|}
\hline $\begin{array}{c}\text { Sampling } \\
\text { year }\end{array}$ & Locality & Period & Approach & Field work & Type of analysis & Reference & Code \\
\hline 1988-1989 & $\begin{array}{l}\text { Boqueirão } \\
\text { and South of } \\
\text { Island Vitória, } \\
\text { Ubatuba }\end{array}$ & $\begin{array}{c}\text { daily } \\
\text { sampling } \\
\text { 1988: 12/ } \\
\text { Feb-15/Mar } \\
\text { \& 10/Aug-4/ } \\
\text { Sep 1989: } \\
\text { 17/Jan-27/ } \\
\text { Feb \& 8-28/ } \\
\text { Jul }\end{array}$ & $\begin{array}{l}\text { space-time } \\
\text { distribution in } \\
\text { phytoplankton } \\
\text { abundance }\end{array}$ & $\begin{array}{l}4 \text { sites; surface, } \\
50 \% \text { and } 1 \% \text { light; } \\
\text { Van Dorn bottle }\end{array}$ & $\begin{array}{l}\text { Utermöhl's } \\
\text { settling } \\
\text { technique }\end{array}$ & $\begin{array}{c}\text { Francos } \\
(1996)\end{array}$ & 10 \\
\hline 1990 & $\begin{array}{l}\text { Between } \\
\text { Ubatumirim } \\
\text { \& Flamengo, } \\
\text { Ubatuba }\end{array}$ & $\begin{array}{l}30 \text { Nov- } \\
16 \text { Dec } \\
\text { every other } \\
\text { day }\end{array}$ & $\begin{array}{l}\text { observation of bloom } \\
\text { patch evolution }\end{array}$ & $\begin{array}{l}20 \text { sites; surface; } \\
\text { sampling with bot- } \\
\text { tle (?); } 1 \text { site with } \\
\text { vertical sampling }\end{array}$ & $\begin{array}{l}\text { Utermöhl's } \\
\text { settling } \\
\text { technique }\end{array}$ & $\begin{array}{l}\text { Gianesella-Galvão } \\
\text { et al. (1995) }\end{array}$ & 11 \\
\hline 1991 & $\begin{array}{l}\text { São Sebastião } \\
\text { Channel }\end{array}$ & October & $\begin{array}{l}\text { assessment of } \\
\text { plankton community } \\
\text { and environmental } \\
\text { parameters }\end{array}$ & $\begin{array}{l}\text { one sampling at } \\
\text { each of the } 20 \text { sites; } \\
\text { surface, mid-water } \\
\& \text { bottom; bottle (?); } \\
\text { surface tows with } \\
\text { net of } 30 \mu \mathrm{m} \text { mesh }\end{array}$ & $\begin{array}{l}\text { Utermöhl's } \\
\text { settling technique } \\
\text { for bottle } \\
\text { samples; common } \\
\text { species from } \\
\text { net samples in } \\
\text { microscope slides }\end{array}$ & $\begin{array}{l}\text { Gianesella et al. } \\
\text { (1999) }\end{array}$ & 12 \\
\hline 1991 & $\begin{array}{l}\text { Bertioga } \\
\text { Channel, } \\
\text { Santos }\end{array}$ & $\begin{array}{c}18 \text { July } \\
\text { (neap tide) \& } \\
27 \text { July } \\
\text { (spring tide) }\end{array}$ & $\begin{array}{l}\text { assessment of } \\
\text { plankton community } \\
\text { and environmental } \\
\text { parameters }\end{array}$ & $\begin{array}{l}\text { nine sampling sites; } \\
\text { surface \& near bot- } \\
\text { tom; bottle (?); one } \\
\text { series at ebb tide and } \\
\text { another at flood tide }\end{array}$ & $\begin{array}{l}\text { Utermöhl's set- } \\
\text { tling technique } \\
\text { only for sites } 1 \text {, } \\
5 \text { and } 9 \text { (pigment } \\
\text { analysis for all } \\
9 \text { sites) }\end{array}$ & $\begin{array}{l}\text { Gianesella et al. } \\
\text { (2000) }\end{array}$ & 13 \\
\hline 1998 & $\begin{array}{l}\text { Ubatuba, } \\
\text { Santos, Praia } \\
\text { Grande }\end{array}$ & $\begin{array}{l}\text { 5-8 March \& } \\
\text { 5-7 April }\end{array}$ & $\begin{array}{l}\text { eutrophication vs. } \\
\text { phytoplankton } \\
\text { (emphasis in primary } \\
\text { production, pig- } \\
\text { ments, overall cell } \\
\text { abundances and } \\
\text { environmental pa- } \\
\text { rameters) }\end{array}$ & $\begin{array}{l}27 \text { sites in Ubatuba, } \\
12 \text { sites in Santos, } \\
20 \text { sites in Praia } \\
\text { Grande; surface; } \\
\text { Van Dorn bottle }\end{array}$ & $\begin{array}{l}\text { Utermöhl's } \\
\text { settling } \\
\text { technique }\end{array}$ & $\begin{array}{l}\text { Frazão } \\
(2001)\end{array}$ & 14 \\
\hline 1999-2000 & $\begin{array}{l}\text { Santos \& } \\
\text { São Vicente }\end{array}$ & $\begin{array}{c}\text { August } 1999 \\
\text { \& January } \\
2000\end{array}$ & $\begin{array}{l}\text { tide vs. } \\
\text { phytoplankton } \\
\text { (emphasis in overall } \\
\text { cell abundances } \\
\text { and environmental } \\
\text { parameters) }\end{array}$ & $\begin{array}{l}3 \text { sites; neap and } \\
\text { spring tides; } \\
\text { surface, mid-photic } \\
\text { layer, Secchi depth; } \\
\text { Van Dorn bottle }\end{array}$ & $\begin{array}{l}\text { Utermöhl's } \\
\text { settling } \\
\text { technique }\end{array}$ & $\begin{array}{l}\text { Moser et al. } \\
\text { (2002) }\end{array}$ & 15 \\
\hline 2002 & $\begin{array}{l}\text { Capela } \\
\text { Beach, Ilha } \\
\text { Bela }\end{array}$ & $\begin{array}{l}\text { January \& } \\
\text { July }\end{array}$ & $\begin{array}{l}\text { eutrophication vs. } \\
\text { phytoplankton } \\
\text { (emphasis in } \\
\text { pigments, overall } \\
\text { cell abundances } \\
\text { and environmental } \\
\text { parameters) }\end{array}$ & $\begin{array}{l}10 \text { sites; surface; } \\
\text { Van Dorn bottle }\end{array}$ & $\begin{array}{l}\text { Utermöhl's } \\
\text { settling } \\
\text { technique }\end{array}$ & $\begin{array}{l}\text { Saldanha-Correa } \\
\text { \& Gianesella } \\
\text { (2003) }\end{array}$ & 16 \\
\hline 2002 & $\begin{array}{l}\text { Enseada } \\
\text { Beach, } \\
\text { Guarujá }\end{array}$ & $\begin{array}{l}\text { January \& } \\
\text { July }\end{array}$ & $\begin{array}{l}\text { eutrophication vs. } \\
\text { phytoplankton } \\
\text { (emphasis in } \\
\text { pigments, overall } \\
\text { cell abundances } \\
\text { and environmental } \\
\text { parameters) }\end{array}$ & $\begin{array}{l}10 \text { sites; surface; } \\
\text { Van Dorn bottle }\end{array}$ & $\begin{array}{l}\text { Utermöhl's } \\
\text { settling } \\
\text { technique }\end{array}$ & $\begin{array}{c}\text { Gianesella \& } \\
\text { Saldanha-Corrêa } \\
\text { (2003) }\end{array}$ & 17 \\
\hline
\end{tabular}


Villac, M.C. et al.

Table 2. Total number of microalgae species found on the coast of the state of São Paulo per taxonomic group. Codes/numbers in the heading refer to the studies published between 1913 and 2002 (refer to Table 1) and present survey refers to 2004-2006.

Table 2. Número total de espécies de microalgas encontradas no litoral do Estado de São Paulo, segundo grupo taxonômico. Códigos/números no cabeçalho correspondem aos estudos publicados entre 1913 e 2002 (vide Tabela 1) e levantamento atual corresponde ao período de 2004-2006.

\begin{tabular}{lrccccccccccccccccccc}
\hline Total & & $\mathbf{Z}$ & $\mathbf{1}$ & $\mathbf{2}$ & $\mathbf{3}$ & $\mathbf{4}$ & $\mathbf{5}$ & $\mathbf{6}$ & $\mathbf{7}$ & $\mathbf{8}$ & $\mathbf{9}$ & $\mathbf{1 0}$ & $\mathbf{1 1}$ & $\mathbf{1 2}$ & $\mathbf{1 3}$ & $\mathbf{1 4}$ & $\mathbf{1 5}$ & $\mathbf{1 6}$ & $\begin{array}{c}\mathbf{1 7} \\
\text { Present } \\
\text { survey }\end{array}$ \\
\hline Diatoms & 469 & 192 & 29 & 132 & 27 & 52 & 68 & 50 & 3 & 55 & 9 & 38 & 4 & 4 & 10 & 20 & 1 & 11 & 14 & 120 \\
Dinoflagellates & 90 & - & 8 & - & - & - & - & 40 & - & 9 & - & - & 1 & - & 2 & 1 & - & - & 1 & 65 \\
Silicoflagellates & 3 & - & - & - & - & - & - & 2 & - & 1 & 1 & 1 & - & - & - & - & - & - & - & 3 \\
Coccolithophorids & 5 & - & - & - & - & - & - & - & - & - & 4 & 3 & - & - & - & - & - & - & - & - \\
Ebriideans & 2 & - & - & - & - & - & - & - & - & 1 & - & 1 & - & - & - & - & - & - & - & 2 \\
Cyanobacteria & 3 & - & - & - & - & - & - & - & - & - & - & - & 1 & - & - & - & - & - & - & 3 \\
Total & 572 & 192 & 37 & 132 & 27 & 52 & 68 & 92 & 3 & 66 & 14 & 43 & 6 & 4 & 12 & 21 & 1 & 11 & 15 & 193 \\
\hline
\end{tabular}

Table 3. List of species that were most frequently cited in the studies considered in this assessment (published between 1913 and 2002, refer to Table 1) and also recorded in the present data set (2004-2006).

Tabela 3. Lista de espécies mais citadas, considerando tanto os estudos pretéritos (publicados entre 1913 e 2002, listados na Tabela 1) como o presente levantamento (2004-2006).

\begin{tabular}{|c|c|}
\hline $\begin{array}{c}\text { Cited in } 30-50 \% \\
\text { of the studies }\end{array}$ & $\begin{array}{c}\text { Cited in } 51-80 \% \\
\text { of the studies }\end{array}$ \\
\hline Actinoptychus senarius & Asterionellopsis glacialis \\
\hline Bacteriastrum delicatulum & Guinardia striata \\
\hline Cerataulina pelagica & Leptocylindrus danicus \\
\hline Chaetoceros curvisetus & Paralia sulcata \\
\hline Chaetoceros laevis & Thalassionema nitzschioides \\
\hline Chaetoceros lorenzianus & \\
\hline Corethron pennatum & \\
\hline Coscinodiscus oculus-iridis & \\
\hline Cyclotella stylorum & \\
\hline Cylindrotheca closterium & \\
\hline Dactyliosolen fragilissimus & \\
\hline Ditylum brightwellii & \\
\hline Guinardia delicatula & \\
\hline Guinardia flaccida & \\
\hline Gyrosigma balticum & \\
\hline Hemiaulus sinensis & \\
\hline Odontella mobiliensis & \\
\hline Phaeodactylum tricornutum & \\
\hline Proboscia alata & \\
\hline Pseudo-nitzschia "seriata" & \\
\hline Rhizosolenia imbricata & \\
\hline Rhizosolenia setigera & \\
\hline Skeletonema costatum & \\
\hline Stephanopyxis turris & \\
\hline
\end{tabular}

The following taxa have been cited in the literature as bloomforming species, some of them as potentially toxic (according to Hallegraeff et al. 2003, Fukuyo et al. 1990, Odebrecht et al. 2002, Moestrup 2004): the diatoms Asterionellopsis glacialis (Castracane) Round, Cerataulina pelagica (Cleve) Hendey, Coscinodiscus wailesii Gran \& Angst, Cylindrotheca closterium (Ehrenberg) Lewin \&
Reimann, Guinardia delicatula (Cleve) Hasle, Leptocylindrus minimus Gran, Pseudo-nitzschia calliantha Lundholm, Moestrup \& Hasle, Pseudo-nitzschia delicatissima (Cleve) Heiden, Pseudo-nitzschia fraudulenta (Cleve) Hasle, Pseudo-nitzschia multistriata (Takano) Takano, Pseudo-nitzschia pungens (Grunow ex Cleve) Hasle; the dinoflagellates Ceratium fusus (Ehrenberg) Dujardin, Ceratium hircus Schröder, Dinophysis acuminata Claparède \& Lachmann, Dinophysis caudata Saville-Kent, Dinophysis rotundata Claparède \& Lachmann, Dinophysis tripos Gourret, Noctiluca scintillans (Macartney) Kofoid et Swezy, Peridinium quinquecorne Abé, Prorocentrum micans Ehrenberg; the silicoflagellate Dictyocha fibula Ehrenberg; and the cyanobacteria Trichodesmium erythraeum Ehrenberg ex Gomont and Trichodesmium thiebautii Gomont ex Gomont. Although some of them have been recorded for many years, only A. glacialis has been implicated in patch formation on the surf-zone that has caused a negative effect to tourism (M.C. Villac, personal observation) and was possibly associated with a fishkill event in Itanhaém in 1978 (Zavala-Camin \& Yamanaka 1980). The recent report of C. wailesii, a large size and thus conspicuous diatom, is in conformity with the contention of Fernandes et al. (2001) that this is indeed a recently introduced species to the Brazilian coast.

\section{Interpreting the species list}

The use and interpretation of this species list require the perception of some constraints. It is not our role to question the identification made by other researchers. On the other hand, the ability to sample, analyze and identify species has evolved over the years and some considerations in this regard are called for.

Some difficulties in updating nomenclature, for instance, are due to the fact that the genera of the nominate species have changed but the revision of all forms/varieties has not been carried out. The reader will find several examples of this case in the species list, such as:

Diploneis crabro Ehrenberg (= Navicula crabro) was updated,

BUT Navicula crabro var. multicostata (Grunow) Grunow was maintained;

Lyrella hennedyi (W. Smith) Stickle \& Mann (= Navicula hennedyi W. Smith) was updated,

BUT Navicula hennedyi var. campechiana Peragallo and Navicula hennedyi var. clavata Cleve were maintained;

Pinnularia stauroptera (Grunov) Rabenhorst (= Navicula stauroptera) was updated,

BUT Navicula stauroptera var. parva (Ehrenberg) Grunow was maintained; 
Psammodictyon panduriforme (Gregory) Mann (= Nitzschia panduriformis) was updated,

BUT Nitzschia panduriformis var. minor Gregory was maintained.

Other cases are even more difficult to resolve as Round et al. (1990; pg. 232) states: "genera in the order Biddulphiales is still in a state of flux. Amphipentas is possibly to be included within Amphitetras but a position in Stictodiscus also needs consideration". The genera Biddulphia Gray, Odontella Agardh and Triceratium Ehrenberg, which are often mentioned in the older literature, fall into this nomenclature/taxonomic problem.

Special taxonomic cases are those regarding the diatoms P. tricorcutum, S. costatum and the genus Pseudo-nitzschia. Frequently considered in the literature as cosmopolitan and opportunistic, S. costatum was the subject of a taxonomic review that revealed that the biodiversity of the genus at any given place is most likely underestimated and it may include more than one species among $S$. ardens Sarno \& Zingone, S. dohrnii Sarno \& Koistra, S. grethae Zingone \& Sarno, S. grevillei Sarno \& Zingone, S. japonicum Zingone \& Sarno, S. marinoi Sarno \& Zingone, S. menzelii Guillard, Carpenter \& Reimann, S. potamus (Weber) Hasle, S. pseudocostatum Medlin, S. subsalsum (Cleve) Bethge and/or S. costatum itself (Sarno et al. 2007). Electron microscopy and/or molecular biology are required to study the biodiversity of Skeletonema species (Kooistra et al. 2008).

The record of Pseudo-nitzschia requires some explanation. Most reports for Brazilian waters follow the nomenclature suggested in Hasle (1965) that divides the species of the genus Nitzschia that form stepped colonies into two complexes: those cells whose widths are equal or smaller than $3 \mu \mathrm{m}$ belong to the "delicatissima complex" and those wider than $3 \mu \mathrm{m}$ belong to the "seriata complex". Alternatively, some publications actually refer just to the occurrence of $N$. delicatissima and/or $N$. seriata. All these can be considered questionable identifications because the methods of analysis used (counting by the settling technique with the inverted microscope) are not adequate for the definite identification, which requires electron microscopy. Therefore, all records were here combined into the two categories suggested by Hasle (1965) and the nomenclature updated to Pseudo-nitzshia (Hasle 1994). The present survey is making an effort to determine the biodiversity of this genus, especially because several species are neurotoxin producers, as mentioned above.

The frequent record of $P$. tricornutum is also troublesome because its minute size would necessarily require the use of electron microscopy to differentiate its fusiform form from other small pennate diatoms, a technique that was not used by any of the published studies considered in this assessment. The presence of the triradiate form (see Hasle \& Syvertsen 1997, page 269) would certainly confirm the report of this species, but the studies in which $P$. tricornutum was found (refer to Appendix) did not make any reference to detailed morphology.

The listing of some species may raise some questioning in regard to ecological issues. This will be especially true for the oldest records from Zimmermann's publications. There is no information about the exact sampling date and the exact locations are not clear. There is mention of "Santos", "Port of Santos" and "Guaruja beach across from Island Santo Amaro", which is the city of Santos. We suspect that some of the samples might have been taken from places of strong freshwater influence, as indicated by the occurrence of the following genera: Amphicampa (Ehrenberg) Ralfs in Pritchard, Cymbella Agardh, Cystopleura Brébisson ex Kuntze, Dicladia Ehrenberg, Encyonema Kützing, Gomphonema Ehrenberg, Hantzschia Grunow, Melosira Agardh, Navicula Bory de Saint-Vincent, Nitzschia Hassall, Stauroneis Ehrenberg, Surirella Turpin. His species list also includes several genera that are usually epiphytic on marine plants or epipelic on sand or silt, such as Licmophora Agardh, Cocconeis Ehrenberg and Surirella Turpin. We also chose not to exclude the mention of Stictodiscus californicus Greville and Campyloneis curvirotunda Tempère et Brun that have been cited in the literature as fossil, nor Goniothecium gastridium Ehrenberg and Goniothecium hispidum Ehrenberg that have been considered as resting spores of Chaetoceros Ehrenberg (Round et al. 1990).

\section{Conclusion}

The composition and abundance of the phytoplankton of a certain region is certainly associated with the local hydrography. The southern portion of the Brazilian coast, where the state of São Paulo is located, is fairly well studied in terms of meso-scale circulation patterns and contribution of water masses on the continental shelf (Emilsson 1960, Matsuura 1986, Castro Filho \& Miranda 1998). The studies considered in this assessment, however, took place in inshore areas where small-scale features should be taken into account. The contribution of warm and oligotrophic waters transported by the Brazil Current will have to be understood in association with different types of landsources of freshwater, and corresponding levels of nutrient enrichment, coupled with various scenarios of local geomorphology. The northern area of the coast, between Ubatuba and Guarujá, is located in more sheltered areas of half-heart small bays with several points of minor freshwater contribution when compared with the much more conspicuous input of freshwater and nutrient enrichment that come from the metropolitan area of Santos, as well as the Cananéia estuarine system at the southernmost limit of the state (Lamparelli \& Moura 1999). Nonethelesss, intrusions of the colder and nutrient-rich South Atlantic Central Water have been related to higher productivity at inshore areas of the northern portion of the coast, especially during the prevailing NE winds of summer months (Castro Filho et al. 1987, Aidar et al. 1993, Gaeta et al. 1995).

The species list provided at present is, therefore, a composite of a very broad spectrum of environmental conditions, dating back to those times of more pristine waters sampled by Zimmermann in the early 1900's. It is beyond the scope of this study to evaluate, case by case, the relationship between species composition and their possible environmental controls. Nevertheless, the results are structured in such a way as to allow the cross-reference between the information provided in Table 1 and the Appendix. A future user will be able to create a species list for a given location, appropriate for a specific need. The understanding of biodiversity and environmental conditions for a particular area of interest could thus result.

\section{Acknowledgements}

This work was funded by Biota-FAPESP to MC Villac, by a FAPESP TT3 fellowship to VAP Cabral-Noronha, and by a PIBIC/ CNPq fellowship to TO Pinto. Field sampling for the beach monitoring program was supported by CETESB and the sampling at the mariculture farm received support from the Butantan Institute through a CAT-CEPID project and from the Mariculture Association of the Cocanha Beach. We are thankful for the suggestions of two anonymous reviewers.

\section{References}

ADL, S.M., SIMPSON, A.G.B., FARMER, M.A., ANDERSEN, R.A., ANDERSON, O.R., BARTA, J.R., BOWSER, S.S., BRUGEROLLE, G., FENSOME, R.A., FREDERICQ, S., JAMES, T.Y., KARPOV, S., KUGRENS, P., KRUG, J., LANE, C.E., LEWIS, L.A., LODGE, J., LYNN, D.H., MANN, D.G., MCCOURT, R.M., MENDOZA, L., MOESTRUP, O., MOZLEY-STANDRIDGE, S.E., NERAD, T.A., 
SHEARER, C.A., SMIRNOV, A.V., SPIEGEL, F.W. \&. TAYLOR, M.J.R. 2005. The new higher level classification of eukaryotes with emphasis on the taxonomy of protists. J. Eukaryot. Microbiol. 52(5):399-451.

AIDAR, E., GAETA, S.A., GIANESELLA-GALVÃO, S., KUTNER, M.B.B. \& TEIXEIRA, C. 1993. Ecossistema costeiro subtropical: nutrientes dissolvidos, fitoplâncton e clorofila $a$ e suas relações com as condições oceanográficas na região de Ubatuba, SP. Publ. Esp. Inst. Oceanogr. 10:9-43.

ANDRADE, M.H.A. \& TEIXEIRA, C. 1957. Contribuição para o conhecimento das diatomáceas do Brasil. Bol. Inst. Oceanogr. 8(1-2):171-215.

BARRERA-ALBA, J.J., GIANESELLA-GALVÃO, S.M.F., MOSER, G.A.O. \& SALDANHA-CORREAA, F.M.P. 2008. Bacterial and phytoplankton dynamics in a sub-tropical estuary. Hydrobiologia 598:229-246.

BOLTOVSKOY, A. 1995. Taxonomia y morfologia de los dinoflagelados: métodos de trabajo. In Manual de métodos ficológicos (K. Alveal, M. Ferrario, E.C. Oliveira \& E. Sar, eds.). Universidad de Concepción, Concepción, p. 55-82.

BRANDINI, F.P. 1982. Variação nictemeral de alguns fatores biológicos na região de Cananéia (SP). Arq. Biol. Tecnol. 25(3-4): 313-327.

CARVALHO, J.P. 1950. O plâncton do rio Maria Rodrigues (Cananéia). Bol. Inst. Paulista Oceanogr. 1(1):27-44.

CASTRO FILHO, B.M. \& MIRANDA, L.B. 1998. Physical oceanography of the Western Atlantic continental shelf located between $4^{\circ} \mathrm{N}$ and $34^{\circ} \mathrm{S}$. In The sea (A.R. Robinson \& K.H. Brink, org.). John Wiley \& Sons, New York, v.11, p.209-251.

CASTRO FILHO, B.M., MIRANDA, L.B. \& MIYAO, S. 1987. Condições hidrográficas na plataforma continental ao largo de Ubatuba: variações sazonais e em média escala. Bolm. Inst. Oceanogr. 35(2):135-151.

DREBES, G. 1974. Marines phytoplankton - Eine Auswahl der Helgoländer Planktonalgen. Georg Thieme Verlag, Stuttgart.

EMILSSON, I. 1960. The shelf and coastal waters off southern Brazil. Publ. Inst. Oceanogr. 140:101-112.

FERNANDES, F.L., ZEHNDER-ALVES, L. \& BASSFELD, J.C. 2001. The recently established diatom Coscinodiscus wailesii (Coscinodiscales, Bacillariophyta) in Brazilian waters. I: Remarks on morphology and distribution. Phycol. Res. 49:89-96.

FRANCOS, M.S. 1996. Variações diárias sazonais (verão e inverno) do "standing-stock" do fitoplâncton e da biomassa em termos de clorofila a em duas estações fixas costeiras na região de Ubatuba: lat. $23^{\circ} 31^{\prime} \mathrm{S}$ - long. $45^{\circ} 05^{\prime} \mathrm{W}$ e lat. $23^{\circ} 51^{\prime} \mathrm{S}$ - long $44^{\circ} 56^{\prime} \mathrm{W}$. MSc. Thesis. Universidade de São Paulo, São Paulo.

FRAZÃO, L.R. 2001. Eutrofização por esgotos domésticos e sua relação com a ecologia e fisiologia do fitoplâncton marinho no litoral do Estado de São Paulo: Ubatuba, Praia Grande e Santos. MSc. Thesis. Universidade de São Paulo, SãoPaulo.

FRITZ, L. \& TRIEMER, R.E. 1985. A rapid simple technique utilizing Calcofluor white M2R for the visualization of dinoflagellate thecal plates. J. Phycology 21(4):662-664.

FUKUYO, Y., TAKANO, H., CHIHARA, M. \& MATSUOKA, K. 1990. Red-tide organisms in Japan - an illustrated taxonomic guide. Uchida Rokakucho, Tokyo.

GAETA, S.A., RIBEIRO, S.M.S., LOPES, R.M. \& METZLER, P.M. 1990. Produtividade primária, plâncton e covariáveis ambientais no Canal de São Sebastião durante o inverno. Bol. Inst. Oceanogr. 50(4):963-974.

GAETA, S.A., RIBEIRO, S.M.S., METZLER, P.M., FRANCOS, M.S. \& ABE, D.S. 1999. Environmental forcing on phytoplankton biomass and primary productivity of the coastal ecosystem in Ubatuba region, southern Brazil. Rev. Bras. Oceanogr. 47:11-27.

GAETA, S.A., TEIXEIRA, C., ABE, D.S., LOPES, R.M. \& SUSINI, S.M. 1995. Size-fractionation of primary production and phytoplankton biomass on inshore waters of the Ubatuba region, Brazil. Publ. Esp. Inst. Oceanogr. 11:153-162.

GALVÃO, S.M.F.G. 1978. Produção primária da Baía de Santos, Estado de São Paulo. MSc. Thesis. Universidade de São Paulo, São Paulo.
GIANESELLA \& SALDANHA-CORRÊA 2003. Avaliação da comunidade fitoplanctônica na ára adjacente ao emissário submarino de esgotos na Praia da Enseada, Guarujá (SP), em janeiro e julho de 2002. In Anais III Congr. Bras. Pesq. Amb. CR-Rom.

GIANESELLA, S.M.F., KUTNER, M.B.B., SALDANHA-CORRÊA, F.M.P. \& POMPEU, M. 1999. Assessment of plankton community and environmental conditions in São Sebastião Channel prior to the construction of a produced water outfall. Rev. Bras. Oceanogr. 47(1):29-46.

GIANESELLA, S.M.F., SALDANHA-CORRÊA, F.M.P. \& TEIXEIRA, C. 2000. Tidal effects on nutrients and phytoplankton distribution in Bertioga Channel, São Paulo, Brazil. Aq. Ecos. Health \& Management 3:533-544.

GIANESELLA-GALVÃO, S.M.F., COSTA, M.P.F. \& KUTNER, M.B.B. 1995. Bloom of Oscillatoria (Trichodesmium) erythraea (Ehr.) Kutz. in coastal waters of the Southern Atlantic. Publ. Esp. Inst. Oceanogr. $11: 133-140$

GUIRY, M.D. \& GUIRY, G.M. 2008. AlgaeBase: World-wide electronic publication. National University of Ireland, Galway. http://www. algaebase.org, accessed in June 2008.

HALleGRAeFF, G.M., ANDERSO, D.M., CEMBELlA, A.D. \& ENEVOLDSEN, H.O. 2003. Manual on harmful marine microalgae. Unesco, Paris.

HASLE, G.R. \& FRYXELL, G.A. 1970. Diatoms: cleaning and mounting for light and electron microscopy. Trans. Amer. Soc. 89(4):469-474.

HASLE, G.R. \& SYVERTSEN, E.E. 1997. Marine diatoms. In Identifying marine phytoplankton (C.R. Tomas, ed.). Academic Press, New York, p. 5-385.

HASLE, G.R. 1965. Nitzschia and Fragilariopsis species studied in the light and electron microscope. II. The group Pseudo-nitzschia. Skr. Nor. Vidensk. Akad. Oslo. I. Mat. Naturvidensk. Kl. 18:1-49.

HASLE, G.R. 1994. Pseudo-nitzschia as a genus distinct from Nitzshia (Bacillariophyceae). J. Phycol. 30(6):1036-1039.

KOOISTRA, W.H.C.F., SARNO, D., BALZANO, S., GU, H., ANDERSEN, R.A. \& ZINGONE, A. 2008. Global diversity and biogeography of Skeletonema species (Bacillariophyta). Protist 159(2):177-193.

KUTNER, M.B.B. 1972. Variação estacional e distribuição do fitoplâncton na região de Cananéia. PhD. Dissertation. Universidade de São Paulo, São Paulo.

LAMPARELLI, C.C. \& MOURA, D.O. 1999. Mapeamento dos ecossistemas costeiros do Estado de São Paulo. Secretaria do Meio Ambiente/CETESB, São Paulo.

LIMA, G.M.S.S.B. 1998. Efeitos do efluente doméstico do emissário submarino de São Sebastião (SP), sobre o fitoplâncton marinho: estudos de campo e de laboratório. PhD. Dissertation. Universidade de São Paulo, São Paulo.

MATSUURA, Y. 1986. Contribuição ao estudo da estrutura oceanográfica da região sudeste entre Cabo Frio (RJ) e Cabo de Santa Marta Grande (SC). Ciência e Cultura 38(8):1439-1450.

MOESTRUP, O. (Ed.) 2004. IOC Taxonomic reference list of toxic algae. Intergovernmental Oceanographic Commission of UNESCO, Paris. http:// www.bi.ku.dk/ioc/default.asp, accessed in June 2008.

MOSER, G.A.O., GIANESELLA, S.M.F., CATTENA, C.O., DAVID, C.J., BARRERA-ALBA, J.J., SALDANHA-CORRÊA, F.M.P. \& BRAGA, E.S. 2002. Influência das marés sobre o fitoplâncton no sistema estuarino de São Vicente e Santos. In Anais II Congr. Bras. Pesq. Amb. CR-Rom

MÜLLER-MELCHERS, F.C. 1955. Las diatomeas del plancton marino de las costas del Brasil. Bol. Inst. Oceanogr. 6(1-2):93-141.

ODEBRECHT, C., AZEVEDO, S.M.F., GARCIA, V.L.M., HUSZAR, V.L.M., PROENÇA, L.A.O., RÖRIG, L.R., TENENBAUM, D.R., VILLAC, M.C. \& YUNES, J.S. 2002. Floraciones de microalgas nocivas en Brasil: estado del arte y proyectos en curso. In Floraciones algales nocivas en el Cono Sur Americano (E. Sar, M. Ferrario \& B. Reguera, eds.). Editora del Instituto Espanhol de Oceanografia, p. 219-233. 
OLIVEIRA, I.R. 1980. Distribuição das diatomáceas epífitas na região de Ubatuba. MSc. Thesis. Universidade de São Paulo, São Paulo.

OLIVEIRA, I.R. 1988. Fitoplâncton e parâmetros físico-químicos do Rio Una do Prelado (SP): composição, distribuição espacial e variação sazonal. $\mathrm{PhD}$. Dissertation. Universidade de São Paulo, São Paulo.

ROUND, F.E., CRAWFORD, R.M. \& MANN, D.G. 1990. The diatoms. Cambridge University Press, Cambridge.

SALDANHA-CORREA, F.M.P. \& GIANESELLA, S.M.F. 2003. Avaliação do fitoplâncton nas águas adjacentes ao difusor do emissário de esgotos do Saco da Capela, Ilha Bela (SP), em janeiro e julho de 2002. In Anais III Congr. Bras. Pesq. Amb. CR-Rom.

SALDANHA-CORRÊA, F.M.P. \& GIANESELLA, S.M.F. 2004. A microcosm approach on the potential effects of the vertical mixing of water masses over the primary productivity and phytoplankton biomass in the southern Brazilian coastal region. Braz. J. Oceanogr. 52(3/4):167-182.

SARNO, D., KOOISTRA, W., BALZANO, S., HARGRAVES, P. \& ZINGONE, A. 2007. Diversity in the genus Skeletonema (Bacillariophyceae): III. Phylogenetic position and morphological variability of Skeletonema costatum and Skeletonema grevillei, with the description of Skeletonema ardens sp. nov. J. Phycol. 43(1):156-170.

SASSI, R. 1978. Variação sazonal do fitoplâncton e fatores ecológicos básicos da região do Saco da Ribeira (lat. 23 30' S, long. 45o 07’W), Ubatuba, Brasil. MSc. Thesis. Universidade de São Paulo, São Paulo.

SOURNIA, A. 1986. Atlas du phytoplankton marin. Volume I: Introduction, Cyanophycées, Dictyochophycées, Dinophycées et Raphidiophycées. Éditions du Centre National de La Recherche Scientifique, Paris.

SOURNIA, A., CHRETIENNOT-DINET, M.J. \& RICARD, M. 1991 Marine phytoplankton: how many species in the world? J. Plankton Res. 13(5):1093-1099.

STEIDINGER, K.A. \& TANGEN, K. 1997. Dinoflagellates. In Identifying marine phytoplankton (C.R. Tomas, ed.). Academic Press, New York, p. 387-589.
TEIXEIRA, C. 1969. Estudo sobre algumas características do fitoplâncton da região de Cananéia e o seu potencial fotossintético. PhD. Dissertation. Universidade de São Paulo, São Paulo.

THRONDSEN, J. 1997. The planktonic marine flagellates. In Identifying marine phytoplankton (C.R. Tomas, ed.). Academic Press, New York, p. 591-729.

ZAVALA-CAMIN, L.A. \& YAMANAKA, N. 1980. Notas sobre um caso de mortandade de peixes, ocorrida em Itanhaém, São Paulo, Brasil. Bol. Inst. Oceanogr. 29:377.

ZILLMANN, S.M.S. 1990. Distribuição sazonal do fitoplâncton na radial

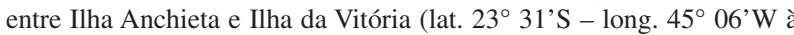
lat. $23^{\circ} 45^{\prime} \mathrm{S}$ - long. $45^{\circ} 01^{\prime} \mathrm{W}$ ) na região de Ubatuba, São Paulo. MSc. Thesis. Universidade de São Paulo, São Paulo.

ZIMMERMANN, C. 1913. I Contribuição para o estudo das diatomáceas dos Estados do Brasil. Brotéria, Série Botânica 11:149-164.

ZIMMERMANN, C. 1914. I Contribuição para o estudo das diatomáceas dos Estados do Brasil (continuação). Brotéria, Série Botânica 12:5-12.

ZIMMERMANN, C. 1915a. II Contribuição para o estudo das diatomáceas dos Estados do Brasil. Brotéria, Série Botânica 13:37-59.

ZIMMERMANN, C. 1915b. III Contribuição para o estudo das diatomáceas dos Estados do Brasil. Brotéria, Série Botânica 13:124-146.

ZIMMERMANN, C. 1916a. IV Contribuição para o estudo das diatomáceas dos Estados do Brasil. Brotéria, Série Botânica 14:85-103.

ZIMMERMANN, C. 1916b. V Contribuição para o estudo das diatomáceas dos Estados do Brasil. Brotéria, Série Botânica 14(n):130-157.

ZIMMERMANN, C. 1917. VI Contribuição para o estudo das diatomáceas dos Estados do Brasil. Brotéria, Série Botânica 15:30-45.

ZIMMERMANN, C. 1918a. VII Contribuição para o estudo das diatomáceas dos Estados do Brasil. Brotéria, Série Botânica 16:8-24.

Recebido em 28/04/08

Versão reformulada recebida em 29/08/08

Publicado em 12/09/08 
Appendix. Check list of microalgae cited for the coast of the state of São Paulo. Code Z and numbers 1-17 in the heading refer to the code of the publications listed in Table 1.

Apêndice. Inventário das microalgas citadas para o litoral do Estado de São Paulo. Código Z e números 1-17 do cabeçalho correspondem aos códigos das publicações listadas na Tabela 1.

\begin{tabular}{lllllllllllllllllllll}
\hline & Present & $Z$ & 1 & 2 & 3 & 4 & 5 & 6 & 7 & 8 & 9 & 10 & 11 & 12 & 13 & 14 & 15 & 16 & 17
\end{tabular}

\section{DIATOMS}

Achnanthes brevipes Agardh

Achnanthes brevipes var. intermedia

(Kützing) Cleve (= Achnanthes subsessilis)

Achnanthes longipes Agardh

$\dagger$ Achnanthes pulchra Zimmermann

Actinocyclus alienus Grunow

Actinocyclus divisus (Grunow) Hustedt

(= Coscinodiscus divisus)

Actinocyclus octonarius Ehrenberg

(= Actinocyclus ehrenbergi ? var.

moniliformis?)

Actinocyclus octonarius Ehrenberg

(= Actinocyclus ehrenbergi)

Actinocyclus octonarius var. crassus (W. Smith)

Hendey (= Actinocyclus crassus)

Actinocyclus platensis Müller Melchers

Actinoptychus adriaticus var. pumila Grunow

Actinoptychus campanulifer Schmidt

Actinoptychus crepido Schmidt

Actinoptychus glabratus var. glabratus Grunow

Actinoptychus ranunculus Brun

* Actinoptychus senarius (Ehrenberg)

Ehrenberg (= Actinopthycus undulatus)

Actinoptychus splendens

(Shadbolt) Ralfs ex Pritchard

Actinoptychus vulgaris Schumann

Actynocyclus curvatulus Janisch in

Schmidt (= Coscinodiscus curvatulus)

Amphicampa eruca Ehrenberg

$\dagger$ Amphipentas juncta (Schmidt) De Toni

Amphiprora alata Kützing

Amphiprora conspicua Greville

Amphiprora pulchra Bailey

$\S$ Amphitetras antediluviana Ehrenberg

(= Biddulphia antediluviana)

Amphora acutiuscula Kützing

Amphora decussata Grunow

Amphora javanica Schmidt

Amphora ovalis (Kützing) Kützing

Amphora salina W. Smith

$\S$ Anaulus australis Drebes \& D. Schulz

Arachnoidiscus ehrenbergii Bailey ex

Ehrenberg

$\dagger$ Ardissonia formosa (Hantzsch) Grunow

Ardissonia fulgens (Greville) Grunow

Ardissonia fulgens var. gigantea

(Lobarz.) Rabenhorst

** Asterionellopsis glacialis (Castracane) Round (= Asterionella glacialis; Asterionella japonica) 
Asteromphalus elegans Greville

Asteromphalus flabellatus (Brébisson) Greville Asteromphalus heptactis (Brébisson) Ralfs

Asteromphalus hookerii Ehrenberg

Asteroplanus karianus (Grunow) Gardner \&

Crawford $(=$ Asterionellopsis kariana $;=$ Asterionella kariana)

Aulacodiscus argus (Ehrenberg) Schmidt § Aulacoseira granulata (Ehrenberg) Simonsen Auliscus caelatus var. latecostata Schmidt Auliscus punctatus Bailey

Auliscus sculptus (W. Smith) Ralfs ex Pritchard (= Auliscus caelatus)

Bacillaria paxillifera (Müller) Hendey (= Bacillaria paradoxa; Nitzschia paradoxa)

* Bacteriastrum delicatulum Cleve

Bacteriastrum furcatum Shadbolt (= Bacteriastrum varians)

Bacteriastrum hyalinum Lauder

$\S$ Bellerochea malleus (Brightwell) Van Heurck Berkeleya scopulorum (Brébisson ex Kützing) Cox (= Navicula scopulorum)

Biddulphia alternans (Bailey) Van Heurck (= Triceratium alternans)

$\dagger$ Biddulphia antediluviana (Ehrenberg)

Van Heurck (?var. excavata? Frenguelli)

Biddulphia biddulphiana (J.E. Smith) Boyer (= Biddulphia pulchella)

Biddulphia dubia (Brightwell) Cleve

Biddulphia obtusa (Kützing) Ralfs

(= Biddulphia roperiana)

§ Biddulphia reticulata Roper

Biddulphia reticulum (Ehrenberg) Boyer

(= Triceratium punctatum)

Biddulphia tuomeyii (Bailey) Roper (= Biddulphia tuomezii)

$\S$ Bleakeleya notata (Grunow) Round

$\dagger$ Caloneis bivittata (Pantocsek) Cleve

Caloneis westii (W. Smith) Hendey

(= Navicula formosa)

Campylodiscus clypeus (Ehrenberg)

Ehrenberg ex Kützing

Campylodiscus daemelianus Grunow

Campylodiscus fastuosus

Ehrenberg (= Campylodiscus thuretii)

$\uparrow$ Campylodiscus guarujanus Zimmermann

$\uparrow$ Campyloneis curvirotunda Tempère et Brun

† Campyloneis maxima Grunow

Catacombus gaillonii (Bory) Williams \& Round (= Synedra gaillonii)

Cerataulina dentata Hasle

* Cerataulina pelagica (Cleve) Hendey

(= Cerataulina bergonii)

Cerataulus smithii Ralfs ex Pritchard $\begin{array}{lllllllllllllllllll}\text { Present } & Z & 1 & 2 & 3 & 4 & 5 & 6 & 7 & 8 & 9 & 10 & 11 & 12 & 13 & 14 & 15 & 16 & 17\end{array}$

$\mathrm{x}$

$\mathrm{X}$

\begin{tabular}{lllllllll}
1 & 2 & 3 & 4 & 5 & 6 & 7 & 8 & \\
\hline & - & - & - & - & - & - & - & -
\end{tabular}

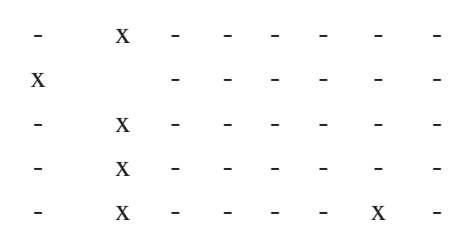

$\mathrm{X}$

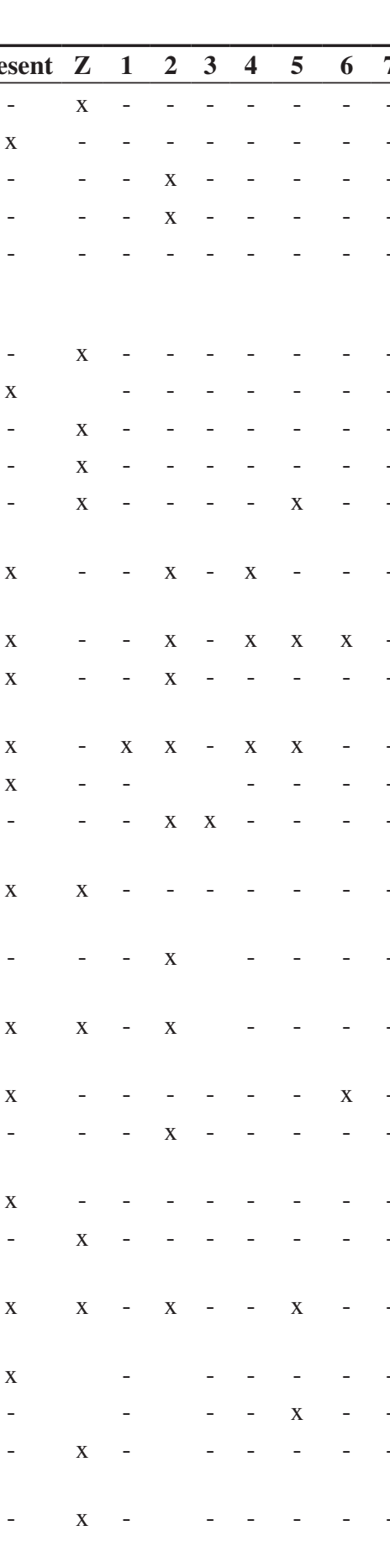

$\mathrm{x}$

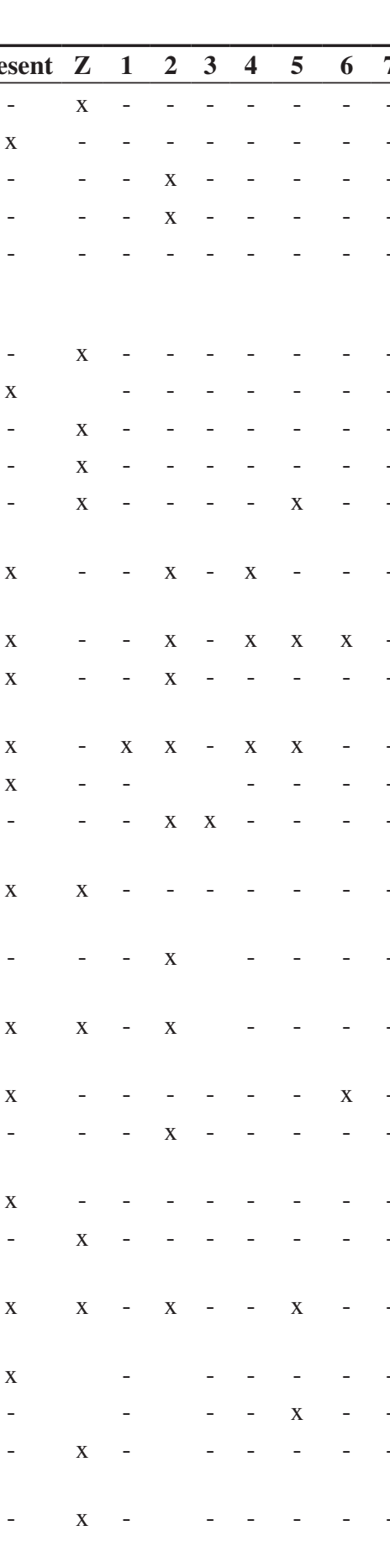

$x$

$\mathrm{x}$

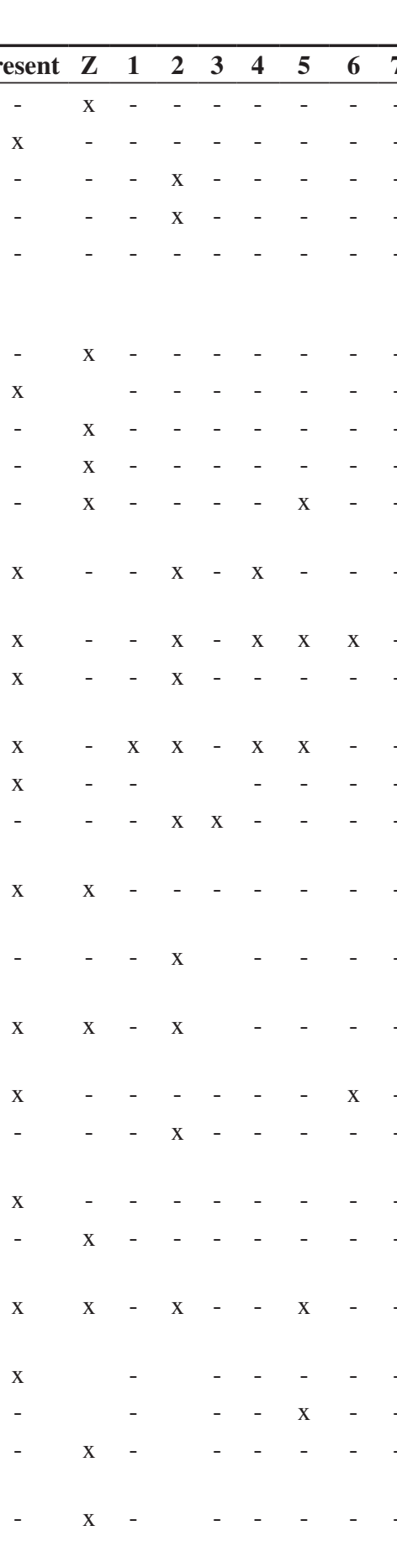

$\mathrm{x}$

$\mathrm{x}$

$\mathrm{x}$

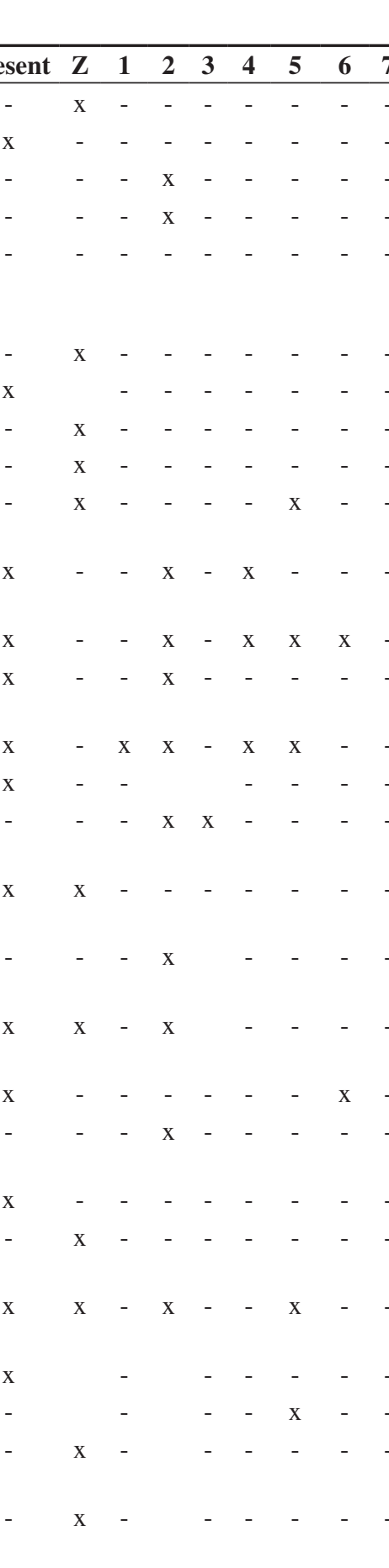
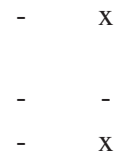
Appendix. Continued...

\begin{tabular}{|c|c|c|c|c|c|c|c|c|c|c|c|c|c|c|c|c|c|c|c|}
\hline & Present & $\mathbf{Z}$ & 1 & 2 & 3 & 4 & 5 & 6 & 7 & 8 & 9 & 10 & 11 & 12 & 13 & 14 & 15 & 16 & 17 \\
\hline Chaetoceros abnormis Proshkina-Lavrenko & $\mathrm{x}$ & - & - & - & - & - & $\mathrm{X}$ & - & - & - & - & - & - & - & - & - & - & - & - \\
\hline$\S$ Chaetoceros aequatorialis Cleve & $\mathrm{x}$ & - & - & - & - & - & - & - & - & - & - & - & - & - & - & - & - & - & - \\
\hline Chaetoceros affinis Lauder & - & - & - & $\mathrm{x}$ & - & $\mathrm{x}$ & - & - & - & - & - & $\mathrm{x}$ & - & - & - & $\mathrm{x}$ & - & - & - \\
\hline Chaetoceros apendiculatus Müller Melchers & - & - & - & $\mathrm{x}$ & - & - & - & - & - & - & - & - & - & - & - & - & - & - & - \\
\hline Chaetoceros atlanticus Cleve & - & - & - & - & - & - & - & $\mathrm{x}$ & & $\mathrm{x}$ & - & - & - & - & - & - & - & - & - \\
\hline Chaetoceros brevis Schütt & $\mathrm{x}$ & - & - & $\mathrm{x}$ & - & - & - & - & - & - & - & - & - & - & - & - & - & - & - \\
\hline$\dagger \S$ Chaetoceros cf. constrictus Gran & $\mathrm{x}$ & - & - & - & - & - & - & - & - & - & - & - & - & - & - & - & - & - & - \\
\hline$\dagger$ Chaetoceros cf. karianus Grunow & - & - & - & $\mathrm{x}$ & - & - & - & - & - & - & - & - & - & - & - & - & - & - & - \\
\hline Chaetoceros coarctatus Lauder & $\mathrm{x}$ & - & - & - & - & - & - & - & - & - & - & $\mathrm{x}$ & - & - & - & - & - & - & - \\
\hline$\S$ Chaetoceros concavicorne Mangin & $\mathrm{x}$ & - & - & - & - & - & - & - & - & - & - & - & - & - & - & - & - & - & - \\
\hline Chaetoceros confertus Müller Melchers & - & - & - & $\mathrm{x}$ & - & - & - & - & - & - & - & - & - & - & - & - & - & - & - \\
\hline $\begin{array}{l}\text { Chaetoceros contortus } \text { Schütt } \\
\text { (= Chaetoceros compressus) }\end{array}$ & $\mathrm{x}$ & - & - & - & - & - & - & - & - & - & - & - & - & - & - & $\mathrm{x}$ & - & - & - \\
\hline Chaetoceros convolutus Castracane & - & - & - & - & - & $\mathrm{x}$ & - & - & - & - & - & - & - & - & - & - & - & - & - \\
\hline$\S$ Chaetoceros costatus Pavillard & $\mathrm{x}$ & - & - & - & - & - & - & - & - & - & - & - & - & - & - & - & - & - & - \\
\hline * Chaetoceros curvisetus Cleve & $\mathrm{x}$ & - & $\mathrm{x}$ & $\mathrm{x}$ & - & $\mathrm{x}$ & $\mathrm{x}$ & & & $\mathrm{x}$ & & & - & - & - & $\mathrm{x}$ & - & - & - \\
\hline$\S$ Chaetoceros dadayi Pavillard & $\mathrm{x}$ & - & - & - & - & - & - & - & - & - & - & - & - & - & - & - & - & - & - \\
\hline$\S$ Chaetoceros danicus Cleve & $\mathrm{x}$ & - & - & - & - & - & - & - & - & - & - & - & - & - & - & - & - & - & - \\
\hline Chaetoceros debilis Cleve & $\mathrm{x}$ & - & - & $\mathrm{x}$ & - & - & & - & - & - & - & - & - & - & - & - & - & - & - \\
\hline Chaetoceros decipiens Cleve & $\mathrm{x}$ & - & - & & - & - & $\mathrm{x}$ & - & - & - & - & $\mathrm{x}$ & - & - & - & - & - & - & - \\
\hline Chaetoceros didymus Ehrenberg & $\mathrm{x}$ & - & - & $\mathrm{x}$ & - & - & - & $\mathrm{x}$ & & & & $\mathrm{x}$ & - & - & $\mathrm{x}$ & - & - & - & - \\
\hline Chaetoceros diversus Cleve & $\mathrm{x}$ & - & - & $\mathrm{x}$ & - & - & - & - & - & - & - & - & - & - & - & - & - & - & - \\
\hline Chaetoceros furcellatus Bailey & - & - & - & $\mathrm{x}$ & - & - & - & - & - & - & - & - & - & - & - & - & - & - & - \\
\hline$\dagger$ Chaetoceros cf. gracilis Schütt & $\mathrm{x}$ & - & - & - & - & - & - & - & - & - & - & - & - & - & - & - & & $\mathrm{x}$ & - \\
\hline$\S$ Chaetoceros laciniosus Schütt & $\mathrm{x}$ & - & - & - & - & - & - & - & - & - & - & - & - & - & - & - & - & - & - \\
\hline * Chaetoceros laevis Leuduger-Fortmorel & $\mathrm{x}$ & - & - & - & & $\mathrm{x}$ & $\mathrm{x}$ & $\mathrm{x}$ & - & $\mathrm{x}$ & - & $\mathrm{x}$ & - & - & - & - & - & - & - \\
\hline$\S$ Chaetoceros lauderi Ralfs & $\mathrm{x}$ & - & - & - & - & - & - & - & - & - & - & - & - & - & - & - & - & - & - \\
\hline * Chaetoceros lorenzianus Grunow & $\mathrm{x}$ & - & - & $\mathrm{x}$ & & $\mathrm{x}$ & $\mathrm{x}$ & & - & & - & $\mathrm{x}$ & - & - & - & - & - & $\mathrm{x}$ & - \\
\hline$\S$ Chaetoceros pelagicus Cleve & $\mathrm{x}$ & - & - & - & - & - & - & - & - & - & - & - & - & - & - & - & - & - & - \\
\hline Chaetoceros pendulus Karsten & $\mathrm{x}$ & - & - & - & - & - & - & $\mathrm{x}$ & - & - & - & - & - & - & - & - & - & - & - \\
\hline Chaetoceros peruvianus Brightwell & $\mathrm{x}$ & - & - & $\mathrm{x}$ & & $\mathrm{x}$ & - & - & - & $\mathrm{x}$ & - & $\mathrm{x}$ & - & - & - & - & - & - & - \\
\hline Chaetoceros pseudocurvisetus Mangin & $\mathrm{x}$ & - & - & $\mathrm{x}$ & - & - & - & - & - & - & - & - & - & - & - & - & - & - & - \\
\hline$\S$ Chaetoceros rostratus Lauder & $\mathrm{x}$ & - & - & - & - & - & - & - & - & - & - & - & - & - & - & - & - & - & - \\
\hline$\S$ Chaetoceros similis Cleve & $\mathrm{x}$ & - & - & - & - & - & - & - & - & - & - & - & - & - & - & - & - & - & - \\
\hline Chaetoceros simplex Ostenfeld & - & - & - & - & - & - & - & $\mathrm{x}$ & - & - & - & - & - & - & - & - & - & - & - \\
\hline Chaetoceros socialis Lauder & $\mathrm{x}$ & & & & & $\mathrm{x}$ & & & - & - & - & - & - & - & - & - & - & - & - \\
\hline Chaetoceros subtilis Cleve & $\mathrm{x}$ & - & - & - & - & - & - & - & - & - & - & - & - & - & - & - & - & $\mathrm{x}$ & - \\
\hline $\begin{array}{l}\text { Chaetoceros subtilis var. abnormis } \\
\text { Prosckina-Lavrenko }\end{array}$ & - & - & - & - & - & - & - & - & - & $\mathrm{x}$ & - & - & - & - & - & - & - & - & - \\
\hline Chaetoceros tenuissimus Meunier & - & - & - & - & - & - & - & - & - & - & - & - & - & - & - & $\mathrm{x}$ & - & $\mathrm{x}$ & $\mathrm{x}$ \\
\hline$\S$ Chaetoceros tetrastichon Cleve & $\mathrm{x}$ & - & - & - & - & - & - & - & - & - & - & - & - & - & - & - & - & - & - \\
\hline$\S$ Chaetoceros tortissimus Gran & $\mathrm{x}$ & - & - & - & - & - & - & - & - & - & - & - & - & - & - & - & - & - & - \\
\hline Climacodium frauenfeldianum Grunow & $\mathrm{x}$ & - & - & - & - & - & - & - & - & $\mathrm{x}$ & - & $\mathrm{x}$ & - & - & - & - & - & - & - \\
\hline Climacosphenia elongata Mereschkowsky & - & $\mathrm{x}$ & - & - & - & - & - & - & - & - & - & - & - & - & - & - & - & - & - \\
\hline Climacosphenia moniligera Ehrenberg & $\mathrm{x}$ & $\mathrm{x}$ & - & $\mathrm{x}$ & - & - & - & $\mathrm{x}$ & - & - & - & - & - & - & - & - & - & - & - \\
\hline $\begin{array}{l}\text { Cocconeis costata var. kerguelensis } \\
\text { (Petit) Cleve }\end{array}$ & - & $\mathrm{x}$ & - & - & - & - & - & - & - & - & - & - & - & - & - & - & - & - & - \\
\hline Cocconeis dirupta Gregory & - & $\mathrm{x}$ & - & - & - & - & - & - & - & - & - & - & - & - & - & - & - & - & - \\
\hline Cocconeis dirupta var. flexella Grunow & - & $\mathrm{x}$ & - & - & - & - & - & - & - & - & - & - & - & - & - & - & - & - & - \\
\hline Cocconeis heteroidea Hantzsch & - & $\mathrm{x}$ & - & - & - & - & - & - & - & - & - & - & - & - & - & - & - & - & - \\
\hline Cocconeis pseudomarginata Gregory & - & $\mathrm{x}$ & - & - & - & - & - & - & - & - & - & - & - & - & - & - & - & - & - \\
\hline Cocconeis scutellum Ehrenberg & - & $\mathrm{x}$ & - & $\mathrm{x}$ & - & - & - & $\mathrm{x}$ & - & - & - & - & - & - & - & - & - & - & - \\
\hline
\end{tabular}


Appendix. Continued...

\begin{tabular}{|c|c|c|c|c|c|c|c|c|c|c|c|c|c|c|c|c|c|c|c|}
\hline & Present & $\mathbf{Z}$ & 1 & 2 & 3 & 4 & 5 & 6 & 7 & 8 & 9 & 10 & 11 & 12 & 13 & 14 & 15 & 16 & 17 \\
\hline$\dagger$ Cocconeis scutellum var. adjuncta Schmidt & - & $\mathrm{x}$ & - & - & - & - & - & - & - & - & - & - & - & - & - & - & - & - & - \\
\hline $\begin{array}{l}\dagger \text { Cocconeis scutellum var. distans (Gregory) } \\
\text { Grunow }\end{array}$ & - & $\mathrm{x}$ & - & - & - & - & - & - & - & - & - & - & - & - & - & - & - & - & - \\
\hline$\dagger$ Cocconeis scutellum var. riparia Grunow & - & $\mathrm{x}$ & - & - & - & - & - & - & - & - & - & - & - & - & - & - & - & - & - \\
\hline $\begin{array}{l}\text { * Corethron pennatum (Grunow) Ostenfeld } \\
(=\text { C. criophilum })\end{array}$ & $\mathrm{x}$ & - & $\mathrm{x}$ & $\mathrm{X}$ & - & $\mathrm{x}$ & $\mathrm{x}$ & $\mathrm{x}$ & - & $\mathrm{x}$ & $\mathrm{x}$ & $\mathrm{x}$ & - & - & - & - & - & - & - \\
\hline $\begin{array}{l}\text { Coscinodiscus apiculatus var. ambigua } \\
\text { A. Grunow }\end{array}$ & - & - & - & $\mathrm{x}$ & - & - & - & - & - & - & - & - & - & - & - & - & - & - & - \\
\hline Coscinodiscus asteromphalus Ehrenberg & - & - & - & $\mathrm{x}$ & - & - & - & - & - & - & - & - & - & - & - & - & - & - & - \\
\hline Coscinodiscus brasiliensis Müller Melchers & - & - & - & $\mathrm{x}$ & - & - & - & $\mathrm{x}$ & - & - & - & - & - & - & - & - & - & - & - \\
\hline $\begin{array}{l}\dagger \text { Coscinodiscus californicus var. ecostatus } \\
\text { Schmidt }\end{array}$ & - & $\mathrm{x}$ & - & - & - & - & - & - & - & - & - & - & - & - & - & - & - & - & - \\
\hline Coscinodiscus concinnus W. Smith & - & - & - & $\mathrm{x}$ & - & & $\mathrm{x}$ & - & - & - & - & - & - & - & - & - & - & - & - \\
\hline Coscinodiscus devius Schmidt & - & - & - & $\mathrm{x}$ & - & - & - & - & - & - & - & - & - & - & & - & - & - & - \\
\hline Coscinodiscus gigas Ehrenberg & - & - & - & $\mathrm{x}$ & - & - & - & - & - & - & - & - & - & - & $\mathrm{x}$ & - & - & - & - \\
\hline Coscinodiscus granii Gough & $\mathrm{x}$ & - & $\mathrm{x}$ & $\mathrm{x}$ & - & - & - & - & - & - & - & - & - & - & $\mathrm{x}$ & - & - & - & - \\
\hline$\dagger$ Coscinodiscus hanckii Grunow & - & $\mathrm{x}$ & & & - & - & - & - & - & - & - & - & - & - & - & - & - & - & - \\
\hline Coscinodiscus heteroporus Ehrenberg & - & - & - & $\mathrm{x}$ & - & - & - & - & - & - & - & - & - & - & - & - & - & - & - \\
\hline Coscinodiscus jonesianus (Greville) Ostenfeld & $\mathrm{x}$ & - & - & $\mathrm{x}$ & - & - & $\mathrm{x}$ & - & - & $\mathrm{x}$ & - & - & - & - & - & - & - & - & - \\
\hline Coscinodiscus kurzii Grunow & - & - & - & - & - & - & $\mathrm{x}$ & - & - & - & - & - & - & - & - & - & - & - & - \\
\hline Coscinodiscus marginatus Ehrenberg & - & - & - & - & - & - & - & - & - & $\mathrm{x}$ & - & - & - & - & - & - & - & - & - \\
\hline Coscinodiscus nitidus Gregory & - & - & - & $\mathrm{x}$ & - & $\mathrm{x}$ & - & $\mathrm{x}$ & - & - & - & - & - & - & - & - & - & - & - \\
\hline Coscinodiscus obscurus Schmidt & - & - & - & $\mathrm{x}$ & - & - & - & - & - & - & - & - & - & - & - & - & - & - & - \\
\hline $\begin{array}{l}\text { * Coscinodiscus oculus-iridis } \\
\text { (Ehrenberg) Ehrenberg }\end{array}$ & - & $\mathrm{x}$ & $\mathrm{x}$ & $\mathrm{x}$ & - & - & $\mathrm{x}$ & $\mathrm{x}$ & - & $\mathrm{x}$ & - & - & - & - & - & - & - & - & - \\
\hline Coscinodiscus pavillardi Forti & - & - & - & $\mathrm{x}$ & - & - & - & - & - & - & - & - & - & - & - & - & - & - & - \\
\hline Coscinodiscus perforatus Ehrenberg & - & - & - & $\mathrm{x}$ & - & - & - & - & - & - & - & - & - & - & - & - & - & - & - \\
\hline $\begin{array}{l}\text { Coscinodiscus punctiger (Castracane } \\
\text { degli Antelminelli) Müller Melchers }\end{array}$ & - & - & - & $\mathrm{x}$ & - & - & - & - & - & - & - & - & - & - & - & - & - & - & - \\
\hline Coscinodiscus radiatus Ehrenberg & - & - & $\mathrm{x}$ & $\mathrm{x}$ & - & - & - & - & - & - & - & - & - & - & - & - & - & - & - \\
\hline $\begin{array}{l}\text { Coscinodiscus radiatus var. minor (Schmidt) } \\
\text { Rattray }\end{array}$ & - & $\mathrm{x}$ & - & - & - & - & - & - & - & - & - & - & - & - & - & - & - & - & - \\
\hline Coscinodiscus robustus var. kittoniana Rattray & - & $\mathrm{x}$ & - & - & - & - & - & - & - & - & - & - & - & - & - & - & - & - & - \\
\hline Coscinodiscus subconcavus Grunow & - & $\mathrm{x}$ & - & - & - & - & - & - & - & - & - & - & - & - & - & - & - & - & - \\
\hline Coscinodiscus symmetricus Greville & - & $\mathrm{x}$ & - & - & - & - & - & - & - & - & - & - & - & - & - & - & - & - & - \\
\hline Coscinodiscus variabilis Frenguelli & - & - & - & $\mathrm{x}$ & & - & - & - & - & - & - & - & - & - & - & - & - & - & - \\
\hline$\S$ Coscinodiscus wailesii Gran \& Angst & $\mathrm{x}$ & - & - & - & - & - & - & - & - & - & - & - & - & - & - & - & - & - & - \\
\hline $\begin{array}{l}\text { Cosmioneis pusilla }(\mathrm{W} . \text { Smith) Mann \& Stickle } \\
\text { (= Navicula pusilla) }\end{array}$ & - & $\mathrm{x}$ & - & - & - & - & - & - & - & - & - & - & - & - & - & - & - & - & - \\
\hline Craticula perrotettii Grunow & - & $\mathrm{x}$ & - & - & - & - & - & - & - & - & - & - & - & - & - & - & - & - & - \\
\hline $\begin{array}{l}\text { Ctenophora pulchella (Ralfs ex Kützing) } \\
\text { Williams \& Round (= Synedra pulchella) }\end{array}$ & - & - & - & - & & $\mathrm{x}$ & - & - & - & - & - & - & - & - & - & - & - & - & - \\
\hline $\begin{array}{l}\text { Cyclotella baltica (Grunow) Håkansson } \\
(=\text { Cyclotella striata } \text { var. baltica) }\end{array}$ & - & $\mathrm{x}$ & - & - & - & - & - & - & - & - & - & - & - & - & - & - & - & - & - \\
\hline$\S$ Cyclotella litoralis Lange \& Syvertsen & $\mathrm{x}$ & - & - & - & - & - & - & - & - & - & - & - & - & - & - & - & - & - & - \\
\hline Cyclotella meneghiniana Kützing & - & $\mathrm{x}$ & & $\mathrm{x}$ & & $\mathrm{x}$ & - & - & - & & - & - & - & - & - & - & - & - & - \\
\hline Cyclotella striata (Kützing) Grunow & - & $\mathrm{x}$ & - & - & & & $\mathrm{x}$ & - & - & $\mathrm{x}$ & - & - & - & - & - & - & - & - & - \\
\hline Cyclotella striata var. mesoleia Grunow & - & $\mathrm{x}$ & - & - & - & - & - & - & - & - & - & - & - & - & - & - & - & - & - \\
\hline * Cyclotella stylorum Brightwell & $\mathrm{x}$ & $\mathrm{x}$ & - & $\mathrm{x}$ & & $\mathrm{x}$ & $\mathrm{x}$ & $\mathrm{x}$ & - & $\mathrm{x}$ & - & - & - & - & - & - & - & - & - \\
\hline $\begin{array}{l}\text { * Cylindrotheca closterium (Ehrenberg) } \\
\text { Lewin \& Reimann }\end{array}$ & $\mathrm{x}$ & - & - & - & & $\mathrm{x}$ & - & $\mathrm{x}$ & - & $\mathrm{x}$ & - & - & $\mathrm{x}$ & - & - & - & - & - & - \\
\hline Cymatosira adaroi Azpeitia Moros & - & - & - & $\mathrm{x}$ & & $\mathrm{x}$ & - & - & - & $\mathrm{x}$ & - & - & - & - & - & - & - & - & - \\
\hline Cymatosira lorenziana Grunow & $\mathrm{x}$ & $\mathrm{x}$ & - & - & - & - & - & - & - & - & - & - & - & - & - & - & - & - & - \\
\hline
\end{tabular}


Appendix. Continued...

Cymbella aspera (Ehrenberg) Cleve

(= Cymbella gastroides)

Cymbella lanceolata (Ehrenberg) Kirchner

Cystopleura gibba (Ehrenberg) Kuntze

Cystopleura gibberula (Ehrenberg) Kuntze

$\dagger$ Cystopleura musculus (Kuetz.) Kunze

Cystopleura turgida (Ehrenberg) Kuntze

$\dagger$ Cystopleura turgida var. granulata (Ehrenberg)

Brun

Cystopleura zebra (Ehrenberg) Kuntze

* Dactyliosolen fragilissimus (Bergon) Hasle

(= Rhizosolenia fragilissima)

Dactyliosolen phuketensis (Sundström) Hasle

(= Rhizosolenia huketensis)

Delphineis surirella (Ehrenberg) Andrews

(= Raphoneis surirella)

$\dagger$ Denticella seticulosa (Greville) Grunow

$\dagger$ Denticula antillarum Cleve et Grunow

Denticula dusenii Cleve

$\S$ Detonula pumila (Castracane) Gran

Dicladia capreola Ehrenberg

Dimeregramma marinum (Gregory) Ralfs ex Pritchard

Diploneis bomboides (Schmidt) Cleve

Diploneis bombus (Ehrenberg) Cleve

Diploneis chersonensis (Grunow) Cleve

Diploneis coffaeiformis (Schmidt) Cleve

Diploneis crabro Ehrenberg

(= Navicula crabro)

Diploneis fusca (Gregory) Cleve

(= Navicula fusca)

Diploneis gruendleri (Schmidt) Cleve

Diploneis interrupta (Kützing) Cleve

(= Navicula interrupta)

Diploneis litoralis (Donkin) Cleve

Diploneis nitescens (Gregory) Cleve

Diploneis ovalis (Hilse) Cleve

Diploneis smithii (Brébisson) Cleve

Diploneis splendida (Gregory) Cleve

(= Navicula splendida)

Diploneis weissflogii (Schmidt) Cleve

* Ditylum brightwellii (T. West) Grunow

Encyonema prostratum (Berkeley) Kützing

Endictya oceanica Ehrenberg

Eucampia cornuta (Cleve) Grunow

Eucampia zoodiacus Ehrenberg

Eunotia serpentina var. transilvanica (Pantocsek)

Hustedt

Eunotogramma variabile Grunow

Eupodiscus antiquus Cox

Eupodiscus radiatus Bailey

Fragilariopsis doliolus (Wallich) Medlin \& Sims

$\begin{array}{lllllllllllllllllll}\text { Present } & Z & 1 & 2 & 3 & 4 & 5 & 6 & 7 & 8 & 9 & 10 & 11 & 12 & 13 & 14 & 15 & 16 & 17\end{array}$

$\begin{array}{llllllllllllllll}3 & 4 & 5 & 6 & 7 & 8 & 9 & 10 & 11 & 12 & 13 & 14 & 15 & 16 & 17\end{array}$

$\begin{array}{lllllllllllllllllll}- & \mathrm{x} & - & - & - & - & - & - & - & - & - & - & - & - & - & - & - & - & - \\ - & \mathrm{x} & - & - & - & - & - & - & - & - & - & - & - & - & - & - & - & - & - \\ - & \mathrm{x} & - & - & - & - & - & - & - & - & - & - & - & - & - & - & - & - & - \\ - & \mathrm{x} & - & - & - & - & - & - & - & - & - & - & - & - & - & - & - & - & - \\ - & \mathrm{x} & - & - & - & - & - & - & - & - & - & - & - & - & - & - & - & - & - \\ - & \mathrm{x} & - & - & - & - & - & - & - & - & - & - & - & - & - & - & - & - & - \\ - & \mathrm{x} & - & - & - & - & - & - & - & - & - & - & - & - & - & - & - & - & -\end{array}$

(= Pseudoeunotia doliolus) 
Appendix. Continued...

\begin{tabular}{|c|c|c|c|c|c|c|c|c|c|c|c|c|c|c|c|c|c|c|c|}
\hline & Present & $\mathbf{Z}$ & 1 & 2 & 3 & 4 & 5 & 6 & 7 & 8 & 9 & 10 & 11 & 12 & 13 & 14 & 15 & 16 & 17 \\
\hline Frickea lewisiana (Greville) Heiden & - & $\mathrm{x}$ & - & - & - & - & - & - & - & - & - & - & - & - & - & - & - & - & - \\
\hline Frustulia rhomboides (Ehrenberg) De Toni & - & & - & - & - & - & $\mathrm{x}$ & - & - & - & - & - & - & - & - & - & - & - & - \\
\hline Glyphodesmis eximia Greville & - & $\mathrm{x}$ & - & - & - & - & - & - & - & - & - & - & - & - & - & - & - & - & - \\
\hline $\begin{array}{l}\text { Gomphonema brasiliense var. demerarae } \\
\text { Grunow }\end{array}$ & - & $\mathrm{x}$ & - & - & - & - & - & - & - & - & - & - & - & - & - & - & - & - & - \\
\hline $\begin{array}{l}\text { Gomphonema exiguum var. arctica (Grunow) } \\
\text { Cleve }\end{array}$ & - & $\mathrm{x}$ & - & - & - & - & - & - & - & - & - & - & - & - & - & - & - & - & - \\
\hline $\begin{array}{l}\dagger \text { Gomphonema subclavatum var. } \\
\text { sparsistriata f. minor Schmidt }\end{array}$ & - & $\mathrm{x}$ & - & - & - & - & - & - & - & - & - & - & - & - & - & - & - & - & - \\
\hline$\dagger$ Goniothecium gastridium Ehrenberg & - & $\mathrm{x}$ & - & - & - & - & - & - & - & - & - & - & - & - & - & - & - & - & - \\
\hline$†$ Goniothecium hispidum Ehrenberg & - & $\mathrm{x}$ & - & - & - & - & - & - & - & - & - & - & - & - & - & - & - & - & - \\
\hline Grammatophora angulosa Ehrenberg & $\mathrm{x}$ & $\mathrm{x}$ & - & - & - & - & - & - & - & - & - & - & - & - & - & - & - & - & - \\
\hline Grammatophora gibberula Kützing & - & $\mathrm{x}$ & - & - & - & - & - & - & - & - & - & - & - & - & - & - & - & - & - \\
\hline Grammatophora marina (Lyngbye) Kützing & $\mathrm{x}$ & $\mathrm{x}$ & - & - & - & - & - & $\mathrm{x}$ & - & - & - & - & - & - & - & - & - & - & - \\
\hline Grammatophora oceanica Ehrenberg & - & $\mathrm{x}$ & - & - & - & - & - & - & - & - & - & - & - & - & - & - & - & - & - \\
\hline Grammatophora serpentina Ehrenberg & - & $\mathrm{x}$ & - & - & - & - & - & - & - & - & - & - & - & - & - & - & - & - & - \\
\hline $\begin{array}{l}\text { * Guinardia delicatula (Cleve) Hasle } \\
(=\text { Rhizosolenia delicatula) }\end{array}$ & $\mathrm{x}$ & - & - & - & - & $\mathrm{x}$ & - & $\mathrm{x}$ & - & - & - & - & $\mathrm{x}$ & - & - & - & - & $\mathrm{x}$ & $\mathrm{x}$ \\
\hline * Guinardia flaccida (Castracane) H. Peragallo & $\mathrm{x}$ & - & - & $\mathrm{x}$ & - & - & $\mathrm{x}$ & $\mathrm{x}$ & - & $\mathrm{x}$ & - & $\mathrm{x}$ & - & - & $\mathrm{x}$ & $\mathrm{x}$ & - & - & $\mathrm{x}$ \\
\hline $\begin{array}{l}\text { ** Guinardia striata } \text { (Stolterfoth) Hasle } \\
(=\text { Rhizosolenia stolterfothii) }\end{array}$ & $\mathrm{x}$ & - & $\mathrm{x}$ & - & - & $\mathrm{x}$ & $\mathrm{x}$ & $\mathrm{x}$ & - & $\mathrm{x}$ & $\mathrm{x}$ & $\mathrm{x}$ & $\mathrm{x}$ & - & - & $\mathrm{x}$ & - & $\mathrm{x}$ & - \\
\hline * Gyrosigma balticum (Ehrenberg) Rabenhorst & $\mathrm{x}$ & - & - & $\mathrm{x}$ & $\mathrm{x}$ & $\mathrm{x}$ & - & - & - & - & - & - & - & - & - & - & - & - & - \\
\hline$†$ Gyrosigma balticum var. wansbeckii Donk & - & - & - & & $\mathrm{x}$ & & - & - & - & - & - & - & - & - & - & - & - & - & - \\
\hline $\begin{array}{l}\text { Gyrosigma fasciola (Ehrenberg) Griffith \& } \\
\text { Henfrey }\end{array}$ & - & - & - & $\mathrm{x}$ & - & - & - & - & - & - & - & - & - & - & - & - & - & - & - \\
\hline $\begin{array}{l}\text { Gyrosigma fasciola var. arcuatum (Donkin) } \\
\text { Cleve }\end{array}$ & - & - & - & - & $\mathrm{x}$ & - & - & - & - & - & - & - & - & - & - & - & - & - & - \\
\hline$\dagger$ Gyrosigma itaparicanum Zimmermann & - & - & - & - & $\mathrm{x}$ & - & - & - & - & - & - & - & - & - & - & - & - & - & - \\
\hline Gyrosigma strigile (W. Smith) Cleve & - & & $\mathrm{x}$ & $\mathrm{x}$ & & - & - & - & - & - & - & - & - & - & - & - & - & - & - \\
\hline Hantzschia amphioxys (Ehrenberg) Grunow & - & $\mathrm{x}$ & - & - & - & - & - & - & - & - & - & - & - & - & - & - & - & - & - \\
\hline Hantzschia amphioxys var. capitata Müller & - & $\mathrm{x}$ & - & - & - & - & - & - & - & - & - & - & - & - & - & - & - & - & - \\
\hline Hantzschia virgata (Roper) Grunow & - & $\mathrm{x}$ & - & - & - & - & - & - & - & - & - & - & - & - & - & - & - & - & - \\
\hline$\S$ Haslea wawrikae (Husedt) Simonsen & $\mathrm{x}$ & - & - & - & - & - & - & - & - & - & - & - & - & - & - & - & - & - & - \\
\hline $\begin{array}{l}\text { Helicotheca tamesis (Shrubsole) Ricard } \\
\text { (= Streptotheca tamesis) }\end{array}$ & $\mathrm{x}$ & - & - & - & - & - & - & - & - & $\mathrm{x}$ & - & - & - & - & - & - & - & - & - \\
\hline Hemiaulus hauckii Grunow ex Van Heurck & $\mathrm{x}$ & - & - & - & - & - & - & $\mathrm{x}$ & - & - & - & - & - & - & - & - & - & - & - \\
\hline Hemiaulus membranaceus Cleve & $\mathrm{x}$ & - & - & - & - & - & $\mathrm{x}$ & $\mathrm{x}$ & - & $\mathrm{x}$ & - & $\mathrm{x}$ & - & - & - & - & - & - & - \\
\hline * Hemiaulus sinensis Greville & $\mathrm{x}$ & - & - & $\mathrm{x}$ & - & - & $\mathrm{x}$ & - & - & $\mathrm{x}$ & $\mathrm{x}$ & $\mathrm{x}$ & - & - & - & $\mathrm{x}$ & - & - & - \\
\hline Hemidiscus cuneiformis Wallich & - & - & - & $\mathrm{x}$ & - & - & & - & - & - & - & - & - & - & - & - & - & - & - \\
\hline $\begin{array}{l}\text { Hemidiscus ovalis (Gersonde) Harwood \& } \\
\text { Maruyama }\end{array}$ & - & - & - & $\mathrm{x}$ & - & - & $\mathrm{x}$ & - & - & - & - & - & - & - & - & - & - & - & - \\
\hline Hyalodiscus scoticus (Kützing) Grunow & - & - & - & $\mathrm{x}$ & - & - & - & - & - & - & - & - & - & - & - & - & - & - & - \\
\hline Hyalodiscus stelliger Bailey & - & $\mathrm{x}$ & - & - & - & - & - & - & - & - & - & - & - & - & - & - & - & - & - \\
\hline $\begin{array}{l}\text { Hyalosynedra laevigata (Grunow) Williams \& } \\
\text { Round (= Synedra laevigata) }\end{array}$ & - & $\mathrm{x}$ & - & - & - & - & - & - & - & - & - & - & - & - & - & - & - & - & - \\
\hline$\dagger$ Hydrosera brasiliensis Zimmermann & - & $\mathrm{x}$ & - & - & - & - & - & - & - & - & - & - & - & - & - & - & - & - & - \\
\hline $\begin{array}{l}\text { Isthmia enervis Ehrenberg } \\
\text { (= Isthmiella enervis) }\end{array}$ & $\mathrm{x}$ & $\mathrm{x}$ & - & $\mathrm{x}$ & - & - & - & - & - & - & - & - & - & - & - & - & - & - & - \\
\hline § Isthmia minima Harvey \& Bailey & $\mathrm{x}$ & - & - & - & - & - & - & - & - & - & - & - & - & - & - & - & - & - & - \\
\hline Isthmia nervosa Kützing & $\mathrm{x}$ & $\mathrm{x}$ & - & & - & - & - & - & - & - & - & - & - & - & - & - & - & - & - \\
\hline Lauderia annulata Cleve (= Lauderia borealis) & $\mathrm{x}$ & - & - & $\mathrm{x}$ & - & $\mathrm{x}$ & - & - & - & $\mathrm{x}$ & - & - & - & - & - & $\mathrm{x}$ & - & - & - \\
\hline ** Leptocylindrus danicus Cleve & $\mathrm{x}$ & - & - & $\mathrm{x}$ & - & - & $\mathrm{x}$ & $\mathrm{x}$ & - & $\mathrm{x}$ & $\mathrm{x}$ & $\mathrm{x}$ & - & $\mathrm{x}$ & - & $\mathrm{x}$ & - & - & $\mathrm{x}$ \\
\hline
\end{tabular}


Appendix. Continued...

$\begin{array}{lllllllllllllllllll}\text { Present } & \mathrm{Z} & 1 & 2 & 3 & 4 & 5 & 6 & 7 & 8 & 9 & 10 & 11 & 12 & 13 & 14 & 15 & 16 & 17\end{array}$

Leptocylindrus mediterraneus (Peragallo) Hasle (= Dactyliosolen mediterraneus)

Leptocylindrus minimus Gran

Licmophora lyngbyei (Kützing) Grunow ex

Van Heurck (= Licmophora abbreviata)

$\dagger$ Licmophora tincta (Agardh) Grunow

Lioloma pacificum (Cupp) Hasle

(= Thalassiothrix mediterranea var. pacifica)

Lithodesmium undulatum Ehrenberg

Lyrella hennedyi (W. Smith) Stickle \& Mann

(= Navicula hennedyi)

Lyrella lyra (Ehrenberg) Karajeva (= Navicula

lyra $=$ Navicula lyra var. ehrenbergi)

Martyana martyi (Héribaud) Round (= Opephora martyi)

Mastogloia apiculata W. Smith

Mastogloia binotata (Grunow) Cleve

Mastogloia brauni Grunow

Mastogloia decussata Grunow

Mastogloia fimbriata (Brightwell) Cleve

$\dagger$ Mastogloia smithii var. pusilla Grunow

Mastogloia splendida (Gregory) Cleve

Melosira borreri Greville

Melosira granulata var. angustissima Müller

Melosira moniliformis (Müller) Agardh

Melosira setosa Greville

Melosira varians Agardh

Meuniera membranacea (Cleve) Silva

$\dagger$ Navicula aspera var. vulgaris Cleve

Navicula bacilliformis Grunow

Navicula bottnica Grunow (= Navicula smithii)

Navicula braunii Grunow

Navicula bullata Norman

Navicula clavata var. caribaea (Cleve)

Peragallo

$\dagger$ Navicula crabro var. multicostata (Grunow)

Grunow

Navicula crucicula (W. Smith) Donkin

Navicula dariana Schmidt

Navicula didyma (Ehrenberg) Kützing

Navicula elliptica Kützing

Navicula eximia (Grunow) Grunow

$\dagger$ Navicula floridae Brun

Navicula forcipata var. versicolor Grunow

Navicula gentilis Donkin

$\dagger$ Navicula guarujana Zimmermann

$\dagger$ Navicula hennedyi var. campechiana

Peragallo

$\uparrow$ Navicula hennedyi var. clavata Cleve

Navicula iridis var. affinis (Ehrenberg)

Van Heurck

Navicula latiuscula Kützing

$\dagger$ Navicula liber var. umbilicata Peragallo

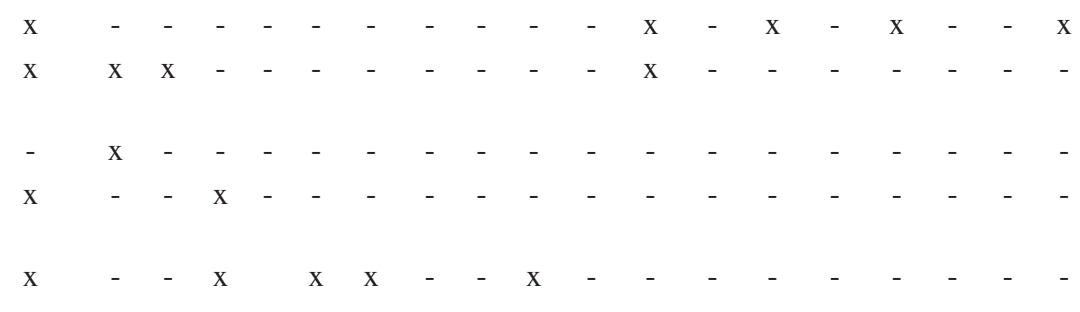


Appendix. Continued...

\begin{tabular}{|c|c|c|c|c|c|c|c|c|c|c|c|c|c|c|c|c|c|c|c|}
\hline & Present & $\mathbf{Z}$ & 1 & 2 & 3 & 4 & 5 & 6 & 7 & 8 & 9 & 10 & 11 & 12 & 13 & 14 & 15 & 16 & 17 \\
\hline Navicula longa Ralfs ex Pritchard & - & $\mathrm{x}$ & - & - & - & - & - & - & - & - & - & - & - & - & - & - & - & - & - \\
\hline Navicula lyra var. gibba Peragallo & - & $\mathrm{x}$ & - & - & - & - & - & - & - & - & - & & - & - & - & - & - & - & - \\
\hline $\begin{array}{l}\text { Navicula marina Ralfs ex Pritchard } \\
(=\text { Navicula punctulata var. marina) }\end{array}$ & - & - & - & $\mathrm{x}$ & $\mathrm{x}$ & - & - & - & - & - & - & - & - & - & - & - & - & - & - \\
\hline Navicula mesolepta Ehrenberg & - & $\mathrm{x}$ & - & - & - & - & - & - & - & - & - & - & - & - & - & - & - & - & - \\
\hline $\begin{array}{l}\text { Navicula mesolepta var. stauroneiformis } \\
\text { Grunow }\end{array}$ & - & $\mathrm{x}$ & - & - & - & - & - & - & - & - & - & - & - & - & - & - & - & - & - \\
\hline Navicula minima Grunow & - & - & - & - & - & $\mathrm{x}$ & - & - & - & - & - & - & - & - & - & - & - & - & - \\
\hline $\begin{array}{l}\text { Navicula nobilis var. dactylus (Ehrenberg) } \\
\text { Van Heurck }\end{array}$ & - & $\mathrm{x}$ & - & - & - & - & - & - & - & - & - & - & - & - & - & - & - & - & - \\
\hline Navicula nodosa Ehrenberg & - & $\mathrm{x}$ & - & - & - & - & - & - & - & - & - & - & - & - & - & - & - & - & - \\
\hline Navicula palpebralis Brébisson & - & - & $\mathrm{x}$ & - & - & - & - & - & - & - & - & - & - & - & - & - & - & - & - \\
\hline Navicula pennata Schmidt & - & - & - & - & $\mathrm{x}$ & & - & - & - & - & - & - & - & - & - & - & - & - & - \\
\hline $\begin{array}{l}\text { Navicula rostellata Kützing } \\
\text { (= Navicula rhyncocephala var. rostellata) }\end{array}$ & - & $\mathrm{x}$ & - & - & - & - & - & - & - & - & - & - & - & - & - & - & - & - & - \\
\hline $\begin{array}{l}\text { Navicula serians var. brachysira (Brébisson) } \\
\text { Van Heurck }\end{array}$ & - & $\mathrm{x}$ & - & - & - & - & - & - & - & - & - & - & - & - & - & - & - & - & - \\
\hline Navicula serians Brébisson ex Kützing & - & $\mathrm{x}$ & - & - & - & - & - & - & - & - & - & - & - & - & - & - & - & - & - \\
\hline Navicula singularis Maillard & - & $\mathrm{x}$ & - & - & - & - & - & - & - & - & - & - & - & - & - & - & - & - & - \\
\hline $\begin{array}{l}\text { Navicula stauroptera var. parva (Ehrenberg) } \\
\text { Grunow }\end{array}$ & - & $\mathrm{x}$ & - & - & - & - & - & - & - & - & - & - & - & - & - & - & - & - & - \\
\hline $\begin{array}{l}\text { Navicula subcarinata (Grunow ex Schmidt) } \\
\text { Hendey (= Navicula lyra var. subcarinata) }\end{array}$ & - & $\mathrm{x}$ & - & - & - & - & - & - & - & - & - & - & - & - & - & - & - & - & - \\
\hline Navicula tabellaria (Ehrenberg) Kützing & - & $\mathrm{x}$ & - & - & - & - & - & - & - & - & - & - & - & - & - & - & - & - & - \\
\hline Navicula trigonocephala (Ehrenberg) Ralfs & - & $\mathrm{x}$ & - & - & - & - & - & - & - & - & - & - & - & - & - & - & - & - & - \\
\hline Navicula tubulosa Brun & - & - & - & - & $\mathrm{x}$ & - & - & - & - & - & - & - & - & - & - & - & - & - & - \\
\hline Navicula viridula (Kützing) Kützing & - & $\mathrm{x}$ & - & - & - & - & - & - & - & - & - & - & - & - & - & - & - & - & - \\
\hline$\dagger$ Navicula viridula f. subsalina Zimmermann & - & $\mathrm{x}$ & - & - & - & - & - & - & - & - & - & - & - & - & - & - & - & - & - \\
\hline $\begin{array}{l}\text { Neocalyptrella robusta (Norman ex Ralfs) } \\
\text { Hernández-Becerril \& Meave del Castillo } \\
\text { (= Rhizosolenia robusta) }\end{array}$ & $\mathrm{x}$ & - & - & $\mathrm{x}$ & - & $\mathrm{x}$ & $\mathrm{x}$ & - & - & - & - & - & - & - & - & - & - & - & - \\
\hline Nitzschia angularis W. Smith & - & - & - & - & - & $\mathrm{x}$ & - & - & - & - & - & - & - & - & - & - & - & - & - \\
\hline Nitzschia bilobata W. Smith & - & - & $\mathrm{x}$ & - & - & - & - & - & - & - & - & - & - & - & - & - & - & - & - \\
\hline Nitzschia circumsuta (Bailey) Grunow & - & $\mathrm{x}$ & - & - & - & - & - & - & - & - & - & - & - & - & - & - & - & - & - \\
\hline Nitzschia granulata Grunow & - & - & - & $\mathrm{x}$ & - & - & - & - & - & - & - & - & - & - & - & - & - & - & - \\
\hline Nitzschia littoralis Grunow & - & - & - & $\mathrm{x}$ & - & - & - & - & - & - & - & - & - & - & - & - & - & - & - \\
\hline $\begin{array}{l}\text { Nitzschia longissima (Brébisson in Kützing) } \\
\text { Ralfs }\end{array}$ & - & - & - & - & - & $\mathrm{x}$ & $\mathrm{x}$ & $\mathrm{x}$ & - & - & - & - & - & - & - & - & - & - & - \\
\hline Nitzschia lorenziana Grunow & - & - & - & - & - & - & $\mathrm{x}$ & - & - & $\mathrm{x}$ & - & - & - & - & - & - & - & - & - \\
\hline Nitzschia obtusa var. nana Grunow & - & $\mathrm{x}$ & - & - & - & - & - & - & - & - & - & - & - & - & - & - & - & - & - \\
\hline Nitzschia obtusa W. Smith & - & - & - & - & - & - & $\mathrm{x}$ & - & - & - & - & - & - & - & - & - & - & - & - \\
\hline Nitzschia obtusa W. Smith & - & $\mathrm{x}$ & - & - & - & - & - & - & - & - & - & - & - & - & - & - & - & - & - \\
\hline$\dagger$ Nitzschia panduriformis var. minor Gregory & - & $\mathrm{x}$ & - & - & - & - & - & - & - & - & - & - & - & - & - & - & - & - & - \\
\hline$\dagger$ Nitzschia rigida var. rigidula Grunow & - & $\mathrm{x}$ & - & - & - & - & - & - & - & - & - & - & - & - & - & - & - & - & - \\
\hline Nitzschia sigma (Kützing) W. Smith & - & - & - & - & - & - & & $\mathrm{x}$ & - & - & - & - & - & - & - & - & - & - & - \\
\hline $\begin{array}{l}\text { Nitzschia sigma var. sigmatella (Gregory) } \\
\text { Grunow }\end{array}$ & - & - & - & - & - & - & $\mathrm{x}$ & - & - & - & - & - & - & - & - & - & - & - & - \\
\hline Nitzschia tryblionella Hantzsch & - & $\mathrm{x}$ & - & $\mathrm{x}$ & - & - & - & - & - & - & - & - & - & - & - & - & - & - & - \\
\hline $\begin{array}{l}\text { Nitzschia tryblionella var. levidensis (W. Smith) } \\
\text { Grunow }\end{array}$ & - & $\mathrm{x}$ & - & - & - & - & - & - & - & - & - & - & - & - & - & - & - & - & - \\
\hline Nitzschia ventricosa Kitton & - & - & - & $\mathrm{x}$ & - & - & - & - & - & - & - & - & - & - & - & - & - & - & - \\
\hline Nitzschia vermicularis (Kützing) Hantzsch & - & $\mathrm{x}$ & - & - & - & - & - & - & - & - & - & - & - & - & - & - & - & - & - \\
\hline Nitzschia vidovichii Grunow & - & - & - & - & - & - & $\mathrm{x}$ & & - & - & - & - & - & - & - & - & - & - & - \\
\hline
\end{tabular}


Appendix. Continued...

\begin{tabular}{|c|c|c|c|c|c|c|c|c|c|c|c|c|c|c|c|c|c|c|c|}
\hline & Present & $\mathbf{Z}$ & 1 & 2 & 3 & 4 & 5 & 6 & 7 & 8 & 9 & 10 & 11 & 12 & 13 & 14 & 15 & 16 & 17 \\
\hline Nitzschia vivax W. Smith & - & $\mathrm{x}$ & - & - & - & - & - & - & - & - & - & - & - & - & - & - & - & - & - \\
\hline$\dagger$ Nitzshia insignis Gregory & - & $\mathrm{x}$ & - & - & - & - & - & - & - & - & - & - & - & - & - & - & - & - & - \\
\hline$\dagger$ Nitzshia punctata (W. Smith) Grunow & - & $\mathrm{x}$ & - & - & - & - & - & - & - & - & - & - & - & - & - & - & - & - & - \\
\hline Odontella aurita (Lyngbye) Agardh & $\mathrm{x}$ & $\mathrm{x}$ & - & - & - & - & - & - & - & - & - & - & - & - & - & - & - & - & - \\
\hline $\begin{array}{l}\text { Odontella longicruris (Greville) Hoban } \\
\text { (= Biddulphia longicruris) }\end{array}$ & $\mathrm{x}$ & - & - & - & - & $\mathrm{x}$ & $\mathrm{x}$ & $\mathrm{x}$ & - & $\mathrm{x}$ & - & - & - & - & - & - & - & - & - \\
\hline $\begin{array}{l}\text { * Odontella mobiliensis (Bailey) Grunow } \\
\text { (= Biddulphia mobiliensis) }\end{array}$ & $\mathrm{x}$ & $\mathrm{x}$ & $\mathrm{x}$ & $\mathrm{x}$ & - & $\mathrm{x}$ & $\mathrm{x}$ & $\mathrm{x}$ & - & $\mathrm{x}$ & - & $\mathrm{x}$ & - & - & $\mathrm{x}$ & - & - & - & - \\
\hline$\S$ Odontella obtusa Kützing & $\mathrm{x}$ & $\mathrm{x}$ & - & - & - & - & - & - & - & - & - & - & - & - & - & - & - & - & - \\
\hline $\begin{array}{l}\text { Odontella regia (Schultze) Simonsen } \\
\text { (= Biddulphia regia) }\end{array}$ & - & - & - & $\mathrm{x}$ & - & - & - & - & - & $\mathrm{x}$ & - & $\mathrm{x}$ & - & - & - & - & - & - & - \\
\hline $\begin{array}{l}\text { Odontella rhombus (Ehrenberg) Kützing } \\
\text { (= Biddulphia rombus) }\end{array}$ & $\mathrm{x}$ & - & - & $\mathrm{x}$ & - & - & $\mathrm{x}$ & - & - & $\mathrm{x}$ & - & - & - & - & - & - & - & - & - \\
\hline $\begin{array}{l}\text { Odontella sinensis (Greville) Grunow } \\
\text { (= Biddulphia sinensis) }\end{array}$ & $\mathrm{x}$ & - & - & $\mathrm{x}$ & - & - & $\mathrm{x}$ & - & - & $\mathrm{x}$ & - & - & - & - & - & - & - & - & - \\
\hline Odontella turgida (Ehrenberg) De Toni & - & $\mathrm{x}$ & - & - & - & - & - & - & - & - & - & - & - & - & - & - & - & - & - \\
\hline $\begin{array}{l}\text { Palmerina hardmaniana (Greville) Hasle } \\
(=\text { Palmeria hardmaniana } ; \\
=\text { Hemidiscus hardmanianus })\end{array}$ & - & - & - & $\mathrm{x}$ & - & - & $\mathrm{x}$ & - & - & - & - & - & - & - & - & - & - & - & - \\
\hline $\begin{array}{l}\text { ** Paralia sulcata }(\text { Ehrenberg) Cleve } \\
(=\text { Melosira sulcata })\end{array}$ & $\mathrm{x}$ & $\mathrm{x}$ & $\mathrm{x}$ & $\mathrm{x}$ & - & $\mathrm{x}$ & $\mathrm{x}$ & $\mathrm{x}$ & - & $\mathrm{x}$ & - & $\mathrm{x}$ & - & - & $\mathrm{x}$ & $\mathrm{x}$ & - & - & - \\
\hline $\begin{array}{l}\text { Paralia sulcata f. coronata (Ehrenberg) } \\
\text { Grunow }\end{array}$ & - & $\mathrm{x}$ & - & - & - & - & - & - & - & - & - & - & - & - & - & - & - & - & - \\
\hline Paralia sulcata f. radiata Grunow & - & $\mathrm{x}$ & - & - & - & - & - & - & - & - & - & - & - & - & - & - & - & - & - \\
\hline $\begin{array}{l}\text { Petrodictyon gemma (Ehrenberg) Mann } \\
(=\text { Surirella gemma })\end{array}$ & - & $\mathrm{x}$ & $\mathrm{x}$ & $\mathrm{x}$ & - & $\mathrm{x}$ & $\mathrm{x}$ & - & - & - & - & - & - & - & - & - & - & - & - \\
\hline $\begin{array}{l}\text { Petroneis plagiostoma (Grunow) Mann } \\
(=\text { Navicula plagiostoma) }\end{array}$ & - & - & - & - & $\mathrm{x}$ & - & - & - & - & - & - & - & - & - & - & - & - & - & - \\
\hline * Phaeodactylum tricornutum Bohlin & - & - & - & - & - & - & - & $\mathrm{x}$ & - & $\mathrm{x}$ & - & $\mathrm{x}$ & - & - & - & - & - & $\mathrm{x}$ & $\mathrm{x}$ \\
\hline $\begin{array}{l}\text { Pinnularia cardinalis (Ehrenberg) W. Smith } \\
\text { (= Navicula cardinalis) }\end{array}$ & - & $\mathrm{x}$ & - & - & - & - & - & - & - & - & - & - & - & - & - & - & - & - & - \\
\hline Pinnularia latevittata Cleve & - & - & - & - & - & $\mathrm{x}$ & - & - & - & - & - & - & - & - & - & - & - & - & - \\
\hline $\begin{array}{l}\text { Pinnularia stauroptera (Grunow) Rabenhorst } \\
\text { (= Navicula stauroptera) }\end{array}$ & - & $\mathrm{x}$ & - & - & - & - & - & - & - & - & - & - & - & - & - & - & - & - & - \\
\hline $\begin{array}{l}\text { Pinnularia viridis }(\text { Nitzsch) Ehrenberg } \\
\text { (= Navicula viridis) }\end{array}$ & - & $\mathrm{x}$ & - & - & - & - & - & - & - & - & - & - & - & - & - & - & - & - & - \\
\hline$\dagger$ Plagiogramma obesum Greville & - & $\mathrm{x}$ & - & - & - & - & - & - & - & - & - & - & - & - & - & - & - & - & - \\
\hline $\begin{array}{l}\dagger \text { Plagiogramma staurophorum var. robustum } \\
\text { Brun in Tempère }\end{array}$ & - & $\mathrm{x}$ & - & - & - & - & - & - & - & - & - & - & - & - & - & - & - & - & - \\
\hline$\dagger$ Plagiotropis zebra Cleve & - & $\mathrm{x}$ & - & - & - & - & - & - & - & - & - & - & - & - & - & - & - & - & - \\
\hline $\begin{array}{l}\text { Pleurosigma acutum } \mathrm{f} \text {. brasiliana } \\
\text { Müller Melchers }\end{array}$ & - & - & - & $\mathrm{x}$ & - & - & - & - & - & - & - & - & - & - & - & - & - & - & - \\
\hline Pleurosigma acutum Norman ex Ralfs & - & - & - & $\mathrm{x}$ & - & - & - & - & - & - & - & - & - & - & - & - & - & - & - \\
\hline Pleurosigma angulatum (Queckett) W. Smith & - & - & - & - & - & - & - & $\mathrm{x}$ & - & $\mathrm{x}$ & - & - & - & - & - & - & - & - & - \\
\hline $\begin{array}{l}\dagger \text { Pleurosigma angulatum var. densestriata } \\
\text { Andrade \& Teixeira }\end{array}$ & - & - & - & - & $\mathrm{x}$ & - & - & - & - & - & - & - & - & - & - & - & - & - & - \\
\hline Pleurosigma angulatum W.Smith & - & - & - & - & $\mathrm{x}$ & - & - & - & - & - & - & - & - & - & - & - & - & - & - \\
\hline Pleurosigma elongatum $\mathrm{W}$. Smith & - & - & - & - & - & - & - & - & - & $\mathrm{x}$ & - & - & - & - & - & - & - & - & - \\
\hline Pleurosigma formosum $\mathrm{W}$. Smith & - & - & - & - & - & - & - & $\mathrm{x}$ & - & - & - & - & - & - & - & - & - & - & - \\
\hline $\begin{array}{l}\text { Pleurosigma hippocampus (Ehrenberg) } \\
\text { W. Smith }\end{array}$ & - & $\mathrm{x}$ & - & - & - & - & - & - & - & - & - & - & - & - & - & - & - & - & - \\
\hline $\begin{array}{l}\dagger \text { Pleurosigma intermedium var. mauritiana } \\
\text { Grunow }\end{array}$ & - & - & - & - & $\mathrm{x}$ & - & - & - & - & - & - & - & - & - & - & - & - & - & - \\
\hline Pleurosigma naviculaceum Brébisson & - & - & - & $\mathrm{x}$ & $\mathrm{x}$ & $\mathrm{x}$ & - & - & - & $\mathrm{x}$ & - & - & - & - & - & - & - & - & - \\
\hline
\end{tabular}


Appendix. Continued...

\begin{tabular}{|c|c|c|c|c|c|c|c|c|c|c|c|c|c|c|c|c|c|c|c|}
\hline & Present & $\mathbf{Z}$ & 1 & 2 & 3 & 4 & 5 & 6 & 7 & 8 & 9 & 10 & 11 & 12 & 13 & 14 & 15 & 16 & 17 \\
\hline Pleurosigma normanii Ralfs & - & $\mathrm{x}$ & - & $\mathrm{x}$ & $\mathrm{x}$ & - & - & - & - & $\mathrm{x}$ & - & - & - & - & - & - & - & - & - \\
\hline $\begin{array}{l}\dagger \text { Pleurosigma rhomboides (Ehrenberg) } \\
\text { De Toni }\end{array}$ & - & $\mathrm{x}$ & - & - & - & - & - & - & - & - & - & - & - & - & - & - & - & - & - \\
\hline Pleurosigma strigilis W. Smith & - & $\mathrm{x}$ & - & - & - & - & - & - & - & - & - & - & - & - & - & - & - & - & - \\
\hline $\begin{array}{l}\text { Pleurosira laevis (Ehrenberg) Compère } \\
\text { (= Biddulphia laevis) }\end{array}$ & - & - & - & $\mathrm{x}$ & & $\mathrm{x}$ & - & - & - & - & - & - & - & - & - & - & - & - & - \\
\hline$\dagger$ Pleurostauron acutum (W. Smith) Rabenhorst & - & $\mathrm{x}$ & - & - & - & - & - & - & - & - & - & - & - & - & - & - & - & - & - \\
\hline Podosira maxima (Kützing) Grunow & - & - & - & $\mathrm{x}$ & - & - & - & - & - & - & - & - & - & - & - & - & - & - & - \\
\hline Podosira stelliger (Bailey) Mann & - & - & - & $\mathrm{x}$ & - & - & - & - & - & $\mathrm{x}$ & - & - & - & - & - & - & - & - & - \\
\hline $\begin{array}{l}\text { * Proboscia alata (Brightwell) Sündstrom } \\
(=\text { Rhizosolenia alata) }\end{array}$ & $\mathrm{x}$ & - & - & $\mathrm{x}$ & - & - & $\mathrm{x}$ & $\mathrm{x}$ & - & $\mathrm{x}$ & - & $\mathrm{x}$ & - & - & - & - & - & - & - \\
\hline $\begin{array}{l}\text { Psammodictyon panduriforme (Gregory) Mann } \\
\text { (= Nitzschia panduriformis) }\end{array}$ & - & $\mathrm{x}$ & - & - & - & - & $\mathrm{x}$ & $\mathrm{x}$ & - & $\mathrm{x}$ & - & - & - & - & - & - & - & - & - \\
\hline$†$ Pseudoauliscus radiatus (Bailey) Rattraz & - & $\mathrm{x}$ & - & - & - & - & - & - & - & - & - & - & - & - & - & - & - & - & - \\
\hline $\begin{array}{l}\dagger \text { Pseudo-nitzschia “delicatissima" } \\
(=\text { Nitzshia delicatissima) }\end{array}$ & - & - & - & - & - & $\mathrm{x}$ & - & - & - & - & - & - & - & - & - & - & - & $\mathrm{x}$ & $\mathrm{x}$ \\
\hline $\begin{array}{l}\dagger * \text { Pseudo-nitzschia "seriata" } \\
(=\text { Nitzschia seriata })\end{array}$ & - & - & $\mathrm{x}$ & - & - & - & $\mathrm{x}$ & - & - & - & - & - & $\mathrm{x}$ & - & - & - & - & $\mathrm{x}$ & $\mathrm{X}$ \\
\hline $\begin{array}{l}\text { § Pseudo-nitzschia calliantha Lundholm, } \\
\text { Moestrup \& Hasle }\end{array}$ & $\mathrm{x}$ & - & - & - & - & - & - & - & - & - & - & - & - & - & - & - & - & - & - \\
\hline $\begin{array}{l}\text { § Pseudo-nitzschia delicatissima (Cleve) } \\
\text { Heiden }\end{array}$ & $\mathrm{x}$ & - & - & - & - & - & - & - & - & - & - & - & - & - & - & - & - & - & - \\
\hline$\S$ Pseudo-nitzschia fraudulenta (Cleve) Hasle & $\mathrm{x}$ & - & - & - & - & - & - & - & - & - & - & - & - & - & - & - & - & - & - \\
\hline $\begin{array}{l}\S \text { Pseudo-nitzschia multistriata (Takano) } \\
\text { Takano }\end{array}$ & $\mathrm{x}$ & - & - & - & - & - & - & - & - & - & - & - & - & - & - & - & - & - & - \\
\hline $\begin{array}{l}\text { § Pseudo-nitzschia pungens (Grunow ex Cleve) } \\
\text { Hasle }\end{array}$ & $\mathrm{x}$ & - & - & - & - & - & - & - & - & - & - & - & - & - & - & - & - & - & - \\
\hline $\begin{array}{l}\text { Pseudosolenia calcar-avis (Schultze) Sundström } \\
\text { (= Rhizosolenia calcar-avis) }\end{array}$ & $\mathrm{x}$ & - & - & $\mathrm{x}$ & - & - & $\mathrm{x}$ & $\mathrm{x}$ & - & - & - & $\mathrm{x}$ & - & - & - & - & - & - & - \\
\hline Raphoneis castracanei Grunow & - & - & - & $\mathrm{x}$ & - & $\mathrm{x}$ & - & - & - & - & - & - & - & - & - & - & - & - & - \\
\hline Rhabdonema adriaticum Kützing & - & $\mathrm{x}$ & - & $\mathrm{x}$ & - & - & - & - & - & - & - & - & - & - & - & - & - & - & - \\
\hline Rhabdonema arcuatum (Lyngbye) Kützing & - & $\mathrm{x}$ & - & - & - & - & - & - & - & - & - & - & - & - & - & - & - & - & - \\
\hline Rhaphoneis amphiceros (Ehrenberg) Ehrenberg & - & $\mathrm{x}$ & - & - & - & - & - & - & - & - & - & - & - & - & - & - & - & - & - \\
\hline $\begin{array}{l}\text { § Rhizosolenia acuminata (H. Peragallo) } \\
\text { H. Peragallo }\end{array}$ & $\mathrm{x}$ & - & - & - & - & - & - & - & - & - & - & - & - & - & - & - & - & - & - \\
\hline Rhizosolenia bergonii $\mathrm{H}$. Peragallo & - & - & - & $\mathrm{x}$ & - & - & $\mathrm{x}$ & - & - & - & - & - & - & - & - & - & - & - & - \\
\hline$\S$ Rhizosolenia castracanei $\mathrm{H}$. Peragallo & $\mathrm{x}$ & - & & - & - & - & - & - & - & - & - & - & - & - & - & - & - & - & - \\
\hline Rhizosolenia hebetata Bailey & $\mathrm{x}$ & - & & - & - & - & - & - & - & $\mathrm{x}$ & - & - & - & - & - & - & - & - & - \\
\hline $\begin{array}{l}\text { Rhizosolenia hebetata f. semispina (Hensen) } \\
\text { Gran (= Rhizosolenia semispina) }\end{array}$ & - & - & $\mathrm{x}$ & - & - & - & - & - & - & - & - & - & - & - & - & - & - & - & - \\
\hline Rhizosolenia hyalina Ostenfeld & $\mathrm{x}$ & - & - & - & - & - & - & - & - & - & - & $\mathrm{x}$ & - & - & - & - & - & - & - \\
\hline $\begin{array}{l}\text { * Rhizosolenia imbricata } \text { Brightwell } \\
\text { (= Rhizosolenia imbricata var. shrubsolei) }\end{array}$ & $\mathrm{x}$ & - & - & $\mathrm{x}$ & & $\mathrm{x}$ & $\mathrm{x}$ & $\mathrm{x}$ & - & - & - & $\mathrm{x}$ & - & - & - & - & - & - & - \\
\hline$\S$ Rhizosolenia pungens Cleve-Euler & $\mathrm{x}$ & - & - & - & - & - & - & - & - & - & - & - & - & - & - & - & - & - & - \\
\hline * Rhizosolenia setigera Brightwell & $\mathrm{x}$ & - & - & $\mathrm{x}$ & & $\mathrm{x}$ & $\mathrm{x}$ & $\mathrm{x}$ & - & $\mathrm{x}$ & - & $\mathrm{x}$ & - & - & - & - & - & - & - \\
\hline Rhizosolenia styliformis Brightwell & $\mathrm{x}$ & - & - & - & - & & $\mathrm{x}$ & - & - & - & - & $\mathrm{x}$ & - & - & - & - & - & - & - \\
\hline$\dagger$ Schizonema liebmannii Grunow & - & $\mathrm{x}$ & - & - & - & - & - & - & - & - & - & - & - & - & - & - & - & - & - \\
\hline$†$ Schizostauron brasiliense Zimmermann & - & $\mathrm{x}$ & - & - & - & - & - & - & - & - & - & - & - & - & - & - & - & - & - \\
\hline$\dagger$ Schizostauron crucicula Grunow & - & - & - & $\mathrm{x}$ & - & - & - & - & - & - & - & - & - & - & - & - & - & - & - \\
\hline$\dagger *$ Skeletonema costatum (Greville) Cleve & - & - & - & $\mathrm{x}$ & & $\mathrm{x}$ & $\mathrm{x}$ & $\mathrm{x}$ & $\mathrm{x}$ & $\mathrm{X}$ & $\mathrm{x}$ & $\mathrm{x}$ & & $\mathrm{x}$ & $\mathrm{x}$ & $\mathrm{x}$ & $\mathrm{x}$ & - & $\mathrm{x}$ \\
\hline$\S$ Skeletonema tropicum Cleve & $\mathrm{x}$ & - & - & - & - & - & - & - & - & - & - & - & - & - & - & - & - & - & - \\
\hline$\dagger$ Stauroneis acuta var. terryana Tempère & - & $\mathrm{x}$ & - & - & - & - & - & - & - & - & - & - & - & - & - & - & - & - & - \\
\hline Stauroneis phoenicenteron Ehrenberg & - & $\mathrm{x}$ & - & - & - & - & - & - & - & - & - & - & - & - & - & - & - & - & - \\
\hline
\end{tabular}


Appendix. Continued...

\begin{tabular}{|c|c|c|c|c|c|c|c|c|c|c|c|c|c|c|c|c|c|c|c|}
\hline & Present & $\mathbf{Z}$ & 1 & 2 & 3 & 4 & 5 & 6 & 7 & 8 & 9 & 10 & 11 & 12 & 13 & 14 & 15 & 16 & 17 \\
\hline Stauroneis schinzii Brun & - & $\mathrm{x}$ & - & - & - & - & - & - & - & - & - & - & - & - & - & - & - & - & - \\
\hline $\begin{array}{l}\text { Stellarima stellaris (Roper) Hasle \& Sims } \\
\text { (= Coscinodiscus stellaris) }\end{array}$ & - & - & - & $\mathrm{x}$ & - & - & - & - & - & - & - & - & - & - & - & - & - & - & - \\
\hline Stephanopyxis palmeriana (Greville) Grunow & $\mathrm{x}$ & - & - & $\mathrm{x}$ & - & $\mathrm{x}$ & $\mathrm{x}$ & - & - & - & - & - & - & - & - & - & - & - & - \\
\hline $\begin{array}{l}\text { * Stephanopyxis turris (Greville) } \\
\text { Ralfs ex Pritchard }\end{array}$ & $\mathrm{x}$ & - & $\mathrm{x}$ & $\mathrm{x}$ & - & - & $\mathrm{x}$ & - & - & $\mathrm{x}$ & - & $\mathrm{x}$ & - & - & - & - & - & - & - \\
\hline Stictodiscus californicus Greville & - & $\mathrm{x}$ & - & - & - & - & - & - & - & - & - & - & - & - & - & - & - & - & - \\
\hline$\S$ Streptotheca tamesis Shrubsole & $\mathrm{x}$ & - & - & - & - & - & - & - & - & - & - & - & - & - & - & - & - & - & - \\
\hline Striatella unipunctata (Lyngbye) Agardh & - & - & - & - & - & - & $\mathrm{x}$ & - & - & - & - & - & - & - & - & - & - & - & - \\
\hline Surirella davidsonii Schmidt & - & $\mathrm{x}$ & - & - & - & - & - & - & - & - & - & - & - & - & - & - & - & - & - \\
\hline$\S$ Surirella fastuosa (Ehrenberg) Kützing & $\mathrm{x}$ & - & - & - & - & - & - & - & - & - & - & - & - & - & - & - & - & - & - \\
\hline $\begin{array}{l}\S \text { Surirella fastuosa var. cuneata (Schmidt) } \\
\text { H. Peragallo \& M. Peragallo }\end{array}$ & $\mathrm{x}$ & - & - & - & - & - & - & - & - & - & - & - & - & - & - & - & - & - & - \\
\hline Surirella febigerii Lewis & - & $\mathrm{x}$ & - & $\mathrm{x}$ & - & - & $\mathrm{x}$ & - & - & - & - & - & - & - & - & - & - & - & - \\
\hline Surirella gruendleri Janisch & - & $\mathrm{x}$ & - & - & - & - & - & - & - & - & - & - & - & - & - & - & - & - & - \\
\hline Surirella kittoni Schmidt & - & & - & - & - & $\mathrm{x}$ & - & - & - & - & - & - & - & - & - & - & - & - & - \\
\hline Surirella ovalis Brébisson & - & $\mathrm{x}$ & - & - & - & - & - & - & - & - & - & - & - & - & - & - & - & - & - \\
\hline $\begin{array}{l}\text { Surirella ovalis var. ovata (Kützing) } \\
\text { Van Heurck }\end{array}$ & - & $\mathrm{x}$ & - & - & - & - & - & - & - & - & - & - & - & - & - & - & - & - & - \\
\hline Surirella praeclare Schmidt & - & $\mathrm{x}$ & - & - & - & - & - & - & - & - & - & - & - & - & - & - & - & - & - \\
\hline Surirella recedens Schmidt & - & & - & - & - & - & $\mathrm{x}$ & - & - & - & - & - & - & - & - & - & - & - & - \\
\hline Surirella robusta Ehrenberg & - & $\mathrm{x}$ & - & - & - & - & & - & - & - & - & - & - & - & - & - & - & - & - \\
\hline Surirella rorata Frenguelli & - & - & - & $\mathrm{x}$ & - & - & $\mathrm{x}$ & - & - & - & - & - & - & - & - & - & - & - & - \\
\hline Surirella tenera var. nervosa Schmidt & - & $\mathrm{x}$ & - & - & - & - & - & - & - & - & - & - & - & - & - & - & - & - & - \\
\hline Surirella tenera var. splendidula Schmidt et al. & - & $\mathrm{x}$ & - & - & - & - & - & - & - & - & - & - & - & - & - & - & - & - & - \\
\hline $\begin{array}{l}\dagger \text { Synedra affinis var. fasciculata (Kützing) } \\
\text { Grunow }\end{array}$ & - & $\mathrm{x}$ & - & - & - & - & - & - & - & - & - & - & - & - & - & - & - & - & - \\
\hline$\dagger$ Synedra affinis var. hybrida Grunow & - & $\mathrm{x}$ & - & - & - & - & - & - & - & - & - & - & - & - & - & - & - & - & - \\
\hline$\dagger$ Synedra affinis var. intermedia Grunow & - & $\mathrm{x}$ & - & - & - & - & - & - & - & - & - & - & - & - & - & - & - & - & - \\
\hline$\dagger$ Synedra affinis var. obtusa Hustedt & - & $\mathrm{x}$ & - & - & - & - & - & - & - & - & - & - & - & - & - & - & - & - & - \\
\hline$\dagger$ Synedra affinis var. parva Van Heusen & - & $\mathrm{x}$ & - & - & - & - & - & - & - & - & - & - & - & - & - & - & - & - & - \\
\hline $\begin{array}{l}\dagger \text { Synedra affinis var. tabulata (Agardh) } \\
\text { Van Heusen }\end{array}$ & - & $\mathrm{x}$ & - & - & - & - & - & - & - & - & - & - & - & - & - & - & - & - & - \\
\hline Synedra crystallina (Agardh) Kützing & - & & - & $\mathrm{x}$ & - & - & - & - & - & - & - & - & - & - & - & - & - & - & - \\
\hline $\begin{array}{l}\text { Synedra fasciculata (Agardh) Kützing } \\
\text { (= Synedra affinis) }\end{array}$ & - & $\mathrm{x}$ & - & - & - & - & - & - & - & - & - & - & - & - & - & - & - & - & - \\
\hline$\dagger$ Synedra gallioni var. macilenta Peragallo & - & $\mathrm{x}$ & - & - & - & - & - & - & - & - & - & - & - & - & - & - & - & - & - \\
\hline Synedra investiens W. Smith & - & $\mathrm{x}$ & - & - & - & - & - & - & - & - & - & - & - & - & - & - & - & - & - \\
\hline Synedra investiens W. Smith & - & & - & - & - & - & - & $\mathrm{x}$ & - & - & - & - & - & - & - & - & - & - & - \\
\hline Synedra ulna (Nitzsch) Ehrenberg & - & $\mathrm{x}$ & - & - & - & - & - & $\mathrm{x}$ & - & - & - & - & - & - & - & - & - & - & - \\
\hline $\begin{array}{l}\text { Synedra ulna var. amphirhynchus (Ehrenberg) } \\
\text { Grunow }\end{array}$ & - & $\mathrm{x}$ & - & - & - & - & - & - & - & - & - & - & - & - & - & - & - & - & - \\
\hline $\begin{array}{l}\text { Synedra ulna var. amphirhynchus (Ehrenberg) } \\
\text { Grunow }\end{array}$ & - & - & - & $\mathrm{x}$ & - & - & - & - & - & - & - & - & - & - & - & - & - & - & - \\
\hline Synedra ulna var. splendens (Kützing) Brun & - & $\mathrm{x}$ & - & - & - & - & - & - & - & - & - & - & - & - & - & - & - & - & - \\
\hline Synedra ulna var. subaequalis Grunow & - & $\mathrm{x}$ & - & - & - & - & - & - & - & - & - & - & - & - & - & - & - & - & - \\
\hline Terpsinoe americana (Bailey) Ralfs & - & $\mathrm{x}$ & $\mathrm{x}$ & $\mathrm{x}$ & - & - & - & - & - & - & - & - & - & - & - & - & - & - & - \\
\hline $\begin{array}{l}\text { Thalassionema frauenfeldii (Grunow) Hallegraeff } \\
\text { (= Thalassiothrix frauenfeldii) }\end{array}$ & $\mathrm{x}$ & - & $\mathrm{x}$ & - & - & - & - & - & - & - & - & - & - & - & - & $\mathrm{x}$ & - & - & - \\
\hline $\begin{array}{l}\text { **Thalassionema nitzschioides (Grunow) } \\
\text { Mereschkowsky }\end{array}$ & $\mathrm{x}$ & - & $\mathrm{X}$ & $\mathrm{x}$ & - & $\mathrm{x}$ & $\mathrm{x}$ & $\mathrm{X}$ & $x$ & $\mathrm{X}$ & $\mathrm{x}$ & $\mathrm{x}$ & - & - & $x$ & $\mathrm{x}$ & - & - & - \\
\hline $\begin{array}{l}\text { Thalassiosira decipiens (Grunow) Jørgensen } \\
\text { (= Coscinodiscus decipiens) }\end{array}$ & - & $\mathrm{x}$ & - & - & - & - & - & - & - & - & - & - & - & - & - & - & - & - & - \\
\hline
\end{tabular}


Thalassiosira eccentrica (Ehrenberg) Cleve

$\begin{array}{lllllllllllllllllll}- & - & \mathrm{x} & - & - & - & - & - & - & \mathrm{x} & - & - & - & - & - & - & - & - & - \\ - & - & - & \mathrm{x} & - & - & - & - & - & - & - & - & - & - & - & - & - & - & - \\ - & - & - & \mathrm{x} & - & - & - & - & - & - & - & - & - & - & - & - & - & - & - \\ - & - & - & \mathrm{x} & - & - & - & - & - & \mathrm{x} & - & - & - & - & - & - & - & - & -\end{array}$
(= Coscinodiscus excentricus)

Thalassiosira eccentrica var. micropora Grunow (= Coscinodiscus excentricus var. micropora)

Thalassiosira hendeyi Hasle \& Fryxell (= Coscinodiscus hustedtii)

Thalassiosira leptopus (Grunow ex Van Heurck)

Hasle \& Fryxell (= Coscinodiscus lineatus)

Thalassiosira pacifica Gran \& Angst

$\S$ Thalassiosira rotula Meunier

Thalassiosira subtilis (Ostenfeld) Gran

Toxarium undulatum Bailey

(= Synedra undulata)

Trachyneis aspera (Ehrenberg) Cleve

Trachyneis aspera var. intermedia (Grunow)

Cleve (= Navicula aspera var. intermedia)

$\dagger$ Trachysphenia australis var. aucklandica Grunow

Triceratium bergonii Tempère \& Brun

Triceratium biquadratum Janisch

Triceratium distictum Barker \& Meakin

$\dagger$ Triceratium distinctum Janisch

Triceratium favus Ehrenberg

Triceratium favus var. quadrata Grunow

Triceratium formosum Brightwell

Triceratium patagonicum Schmidt

Triceratium pentacrinus (Ehrenberg) Wallich

Triceratium scitulum f. quadrata Schmidt

Tryblionella littoralis (Grunow) Mann

(= Nitzschia littoralis)

DINOFLAGELLATES

$\S$ Alexandrium fraterculus (Balech) Balech

Amphisolenia bidentata Schröder

Ceratium breve (Ostenfeld \& Schmidt)

Schröder

Ceratium carriense Gourret

Ceratium contortum (Gourret) Cleve

Ceratium declinatum (Karsten) Jørgensen

$\S$ Ceratium declinatum var. angusticornum (Peters) Taylor

$\S$ Ceratium declinatum var. majus Jørgensen

Ceratium euarcuatum Jørgensen

Ceratium extensum (Gourret) Cleve

§ Ceratium falcatum (Kofoid) Jørgensen

Ceratium furca (Ehrenberg)

Claparéde \& Lachmann

$\S$ Ceratium furca var. eugrammum (Ehrenberg) Jørgensen

Ceratium fusus (Ehrenberg) Dujardin

Ceratium gibberum Gourret

Ceratium gravidum Gourret

Ceratium hexacanthum Gourret

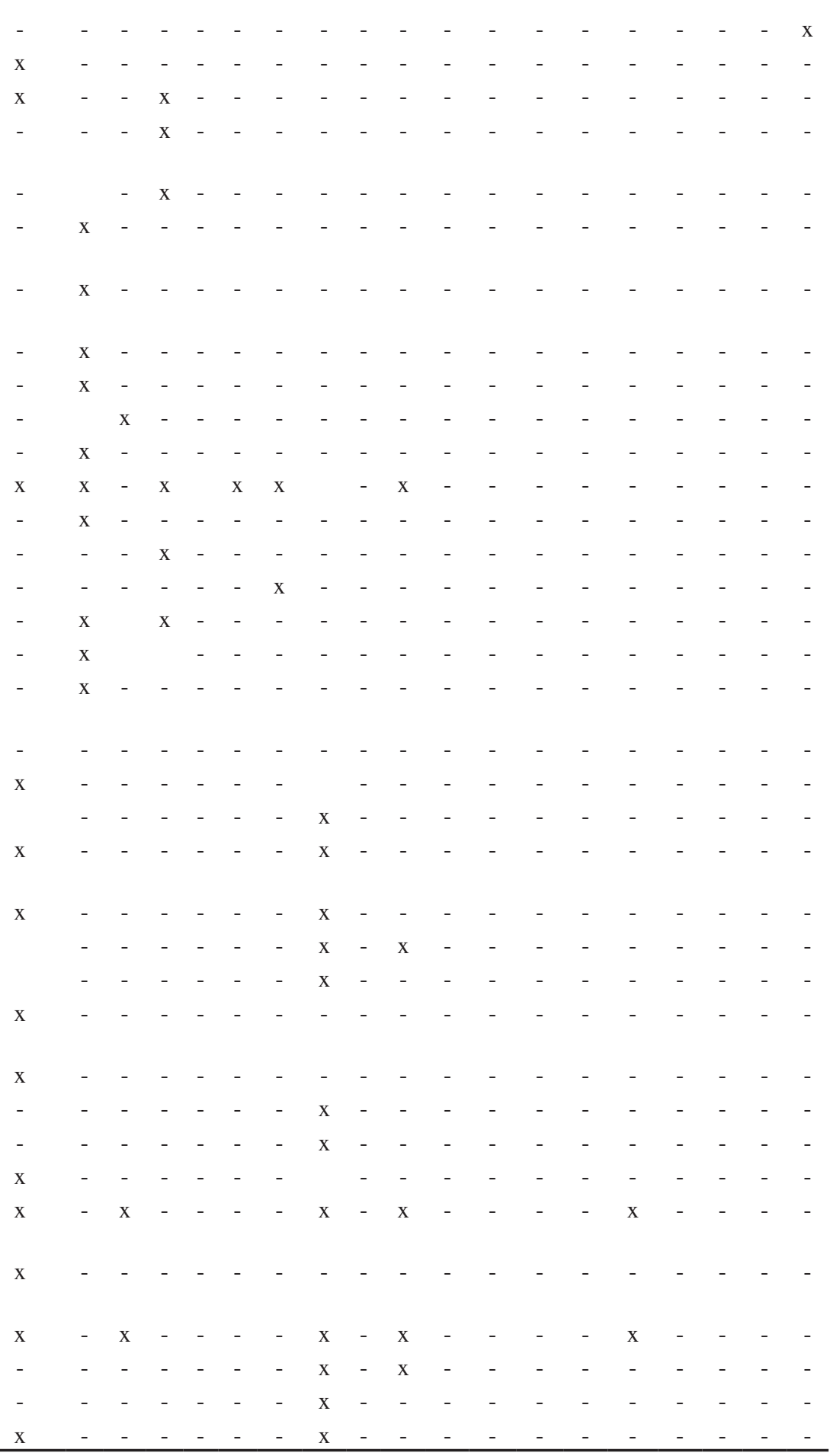


Appendix. Continued...

\begin{tabular}{|c|c|c|c|c|c|c|c|c|c|c|c|c|c|c|c|c|c|c|c|}
\hline & Present & $\mathbf{Z}$ & 1 & 2 & 3 & 4 & 5 & 6 & 7 & 8 & 9 & 10 & 11 & 12 & 13 & 14 & 15 & 16 & 17 \\
\hline$\S$ Ceratium hircus Schröder & $\mathrm{x}$ & - & - & - & - & - & - & - & - & - & - & - & - & - & - & - & - & - & - \\
\hline$\S$ Ceratium horridum (Cleve) Gran & $\mathrm{x}$ & - & - & - & - & - & - & - & - & - & - & - & - & - & - & - & - & - & - \\
\hline$\S$ Ceratium humile Jørgensen & $\mathrm{x}$ & - & - & - & - & - & - & - & - & - & - & - & - & - & - & - & - & - & - \\
\hline Ceratium inflatum (Kofoid) Jørgensen & $\mathrm{x}$ & - & - & - & - & - & - & $\mathrm{x}$ & - & - & - & - & - & - & - & - & - & - & - \\
\hline Ceratium karsteni Pavillard & - & - & - & - & - & - & - & $\mathrm{x}$ & - & - & - & - & - & - & - & - & - & - & - \\
\hline$\S$ Ceratium kofoidii Jørgensen & $\mathrm{x}$ & - & - & - & - & - & - & & - & - & - & - & - & - & - & - & - & - & - \\
\hline Ceratium longirostrum Gourret & - & - & $\mathrm{x}$ & - & - & - & - & $\mathrm{x}$ & - & - & - & - & - & - & - & - & - & - & - \\
\hline $\begin{array}{l}\text { Ceratium lunula (Schimper ex Karsten) } \\
\text { Jørgensen }\end{array}$ & - & - & - & - & - & - & - & $\mathrm{x}$ & - & - & - & - & - & - & - & - & - & - & - \\
\hline$\S$ Ceratium macroceros (Ehrenberg) Vanhöffen & $\mathrm{x}$ & - & - & - & - & - & - & & - & - & - & - & - & - & - & - & - & - & - \\
\hline Ceratium macroceros var. gallicum Kofoid & & - & - & - & - & - & - & $\mathrm{x}$ & - & - & - & - & - & - & - & - & - & - & - \\
\hline Ceratium massiliense (Gourret) Jørgensen & $\mathrm{x}$ & - & - & - & - & - & - & $\mathrm{x}$ & - & - & - & - & - & - & - & - & - & - & - \\
\hline Ceratium pentagonum var. robustom Cleve & - & - & - & - & - & - & - & $\mathrm{x}$ & - & - & - & - & - & - & - & - & - & - & - \\
\hline Ceratium pentagonum var. tenerum Jørgensen & - & - & - & - & - & - & - & $\mathrm{x}$ & - & - & - & - & - & - & - & - & - & - & - \\
\hline$\S$ Ceratium pulchellum Schröder & $\mathrm{x}$ & - & - & - & - & - & - & & - & - & - & - & - & - & - & - & - & - & - \\
\hline Ceratium sumatranum (Karsten) Jørgensen & - & - & - & - & - & - & - & $\mathrm{x}$ & - & - & - & - & - & - & - & - & - & - & - \\
\hline$\S$ Ceratium symmetricum Pavillard & $\mathrm{x}$ & - & - & - & - & - & - & & - & - & - & - & - & - & - & - & - & - & - \\
\hline $\begin{array}{l}\text { Ceratium tenue (Ostenfeld \& Schmidt) } \\
\text { Jørgensen }\end{array}$ & - & - & - & - & - & - & - & $\mathrm{x}$ & - & - & - & - & - & - & - & - & - & - & - \\
\hline Ceratium teres Kofoid & - & - & - & - & - & - & - & $\mathrm{x}$ & - & - & - & - & - & - & - & - & - & - & - \\
\hline$\S$ Ceratium deflexum (Kofoid) Jørgensen & $\mathrm{x}$ & - & - & - & - & - & - & & - & - & - & - & - & - & - & - & - & - & - \\
\hline Ceratium trichoceros (Ehrenberg) Kofoid & $\mathrm{x}$ & - & - & - & - & - & - & $\mathrm{x}$ & - & - & - & - & - & - & - & - & - & - & - \\
\hline Ceratium tripos (Müller) Nitzsch & $\mathrm{x}$ & - & $\mathrm{x}$ & - & - & - & - & $\mathrm{x}$ & - & - & - & - & - & - & - & - & - & - & - \\
\hline$\dagger$ Ceratium tripos var. tripodioides (Jørgensen) & - & - & - & - & - & - & - & $\mathrm{x}$ & - & - & - & - & - & - & - & - & - & - & - \\
\hline
\end{tabular}

Paulsen

$\S$ Ceratium tripos var. atlanticum (Ostenfeld) Paulsen

$\dagger$ Ceratium vultur var. recurvum (Jørgensen) Schiller

$\S$ Corythodinium michaelsarsi (Gaarder) Taylor

$\S$ Corythodinium tesselatum (Stein)

Loeblich Jr. \& Loeblich III

Dinophysis acuminata Claparède \& Lachmann

$\S$ Dinophysis argus (Stein) Abé

Dinophysis caudata Saville-Kent

$\S$ Dinophysis hastata Stein

Dinophysis rapa (Stein) Balech

$\S$ Dinophysis rotundata

Claparède \& Lachmann

Dinophysis tripos Gourret

Goniodoma polyedricum (Pouchet) Jørgensen

$\S$ Gonyaulax cf. verior Sournia

Gonyaulax digitale (Pouchet) Kofoid

$\S$ Gymnodinium catenatum Graham

$\S$ Mesoporos perforatus (Gran) Lillick

(= Porella perforata)

Noctiluca scintillans (Macartney)

Kofoid et Swezy

§ Ornithocercus thumii (Schmidt)

Kofoid \& Skogsberg

$\S$ Oxyphysis oxytoxoides Kofoid

§ Oxytoxum milneri Murray \& Whitting

Oxytoxum scolopax Stein 
Appendix. Continued...

\begin{tabular}{|c|c|c|c|c|c|c|c|c|c|c|c|c|c|c|c|c|c|c|c|}
\hline & Present & $\mathbf{Z}$ & 1 & 2 & 3 & 4 & 5 & 6 & 7 & 8 & 9 & 10 & 11 & 12 & 13 & 14 & 15 & 16 & 17 \\
\hline$\S$ Peridinium quinquecorne Abé & $\mathrm{x}$ & - & - & - & - & - & - & - & - & - & - & - & - & - & - & - & - & - & - \\
\hline Podolampas bipes Stein & $\mathrm{x}$ & - & - & - & - & - & - & $\mathrm{x}$ & - & - & - & - & - & - & - & - & - & - & - \\
\hline$\S$ Podolampas elegans Schütt & $\mathrm{x}$ & - & - & - & - & - & - & - & - & - & - & - & - & - & - & - & - & - & - \\
\hline$\S$ Podolampas palmipes Stein & $\mathrm{x}$ & - & - & - & - & - & - & - & - & - & - & - & - & - & - & - & - & - & - \\
\hline $\begin{array}{l}\text { Prorocentrum compressum (Bailey) } \\
\text { Abé ex Dodge }\end{array}$ & $\mathrm{x}$ & - & - & - & - & - & - & - & - & - & - & - & - & - & - & - & - & - & $\mathrm{x}$ \\
\hline$\S$ Prorocentrum cordatum (Ostenfeld) Dodge & $\mathrm{x}$ & - & - & - & - & - & - & - & - & - & - & - & - & - & - & - & - & - & - \\
\hline Prorocentrum gracile Schütt & $\mathrm{x}$ & - & - & - & - & - & - & - & - & - & - & - & - & - & - & $\mathrm{x}$ & - & - & - \\
\hline Prorocentrum micans Ehrenberg & $\mathrm{x}$ & - & - & - & - & - & - & $\mathrm{x}$ & - & - & - & - & $\mathrm{x}$ & - & - & - & - & - & - \\
\hline$\S$ Prorocentrum sigmoide $\mathrm{Bohm}$ & $\mathrm{x}$ & - & - & - & - & - & - & - & - & - & - & - & - & - & - & - & - & - & - \\
\hline $\begin{array}{l}\text { § Protoperidinium cf. tenuissinum (Kofoid) } \\
\text { Balech }\end{array}$ & $\mathrm{x}$ & - & - & - & - & - & - & - & - & - & - & - & - & - & - & - & - & - & - \\
\hline Protoperidinium crassipes (Kofoid) Balech & - & - & $\mathrm{x}$ & - & - & - & - & - & - & - & - & - & - & - & - & - & - & - & - \\
\hline Protoperidinium depressum (Bailey) Balech & - & - & - & - & - & - & - & $\mathrm{x}$ & - & - & - & - & - & - & - & - & - & - & - \\
\hline Protoperidinium divergens (Ehrenberg) Balech & $\mathrm{x}$ & - & $\mathrm{x}$ & - & - & - & - & - & - & - & - & - & - & - & - & - & - & - & - \\
\hline Protoperidinium grande (Kofoid) Balech & $\mathrm{x}$ & - & - & - & - & - & - & $\mathrm{x}$ & - & - & - & - & - & - & - & - & - & - & - \\
\hline $\begin{array}{l}\text { Protoperidinium pellucidum Bergh ex Loeblich } \\
\text { Jr. \& Loeblich III }\end{array}$ & $\mathrm{x}$ & - & - & - & - & - & - & $\mathrm{x}$ & - & - & - & - & - & - & - & - & - & - & - \\
\hline $\begin{array}{l}\S \text { Protoperidinium asymmetricum (Karsten) } \\
\text { Balech }\end{array}$ & $\mathrm{x}$ & - & - & - & - & - & - & - & - & - & - & - & - & - & - & - & - & - & - \\
\hline$\S \dagger$ Protoperidinium "type" brochii & $\mathrm{x}$ & - & - & - & - & - & - & - & - & - & - & - & - & - & - & - & - & - & - \\
\hline$\S$ Protoperidinium conicum (Gran) Balech & $\mathrm{x}$ & - & - & - & - & - & - & - & - & - & - & - & - & - & - & - & - & - & - \\
\hline$\S \dagger$ Protoperidinium "type" latissimum & $\mathrm{x}$ & - & - & - & - & - & - & - & - & - & - & - & - & - & - & - & - & - & - \\
\hline$\S \dagger$ Protoperidinium "type" leonis & $\mathrm{x}$ & - & - & - & - & - & - & - & - & - & - & - & - & - & - & - & - & - & - \\
\hline$\S \dagger$ Protoperidinium "type" oceanicum & $\mathrm{x}$ & - & - & - & - & - & - & - & - & - & - & - & - & - & - & - & - & - & - \\
\hline$\S †$ Protoperidinium "type" ovatum & $\mathrm{x}$ & - & - & - & - & - & - & - & - & - & - & - & - & - & - & - & - & - & - \\
\hline$\S †$ Protoperidinium "type" pentagonum & $\mathrm{x}$ & - & - & - & - & - & - & - & - & - & - & - & - & - & - & - & - & - & - \\
\hline$\S$ Protoperidinium steinii (Jørgensen) Balech & $\mathrm{x}$ & - & - & - & - & - & - & - & - & - & - & - & - & - & - & - & - & - & - \\
\hline$\S$ Protoperidinium tuba (Schiller) Balech & $\mathrm{x}$ & - & - & - & - & - & - & - & - & - & - & - & - & - & - & - & - & - & - \\
\hline Pseliodinium vaubanii Soumia & - & - & - & - & - & - & - & - & - & $\mathrm{x}$ & - & - & - & - & - & - & - & - & - \\
\hline Pyrocystis lunula (Schütt) Schütt & - & - & - & - & - & - & - & $\mathrm{x}$ & - & - & - & - & - & - & - & - & - & - & - \\
\hline Pyrocystis obtusa Pavillard & $\mathrm{x}$ & - & - & - & - & - & - & - & - & $\mathrm{x}$ & - & - & - & - & - & - & - & - & - \\
\hline$\S$ Pyrophacus horologium Stein & $\mathrm{x}$ & - & - & - & - & - & - & - & - & - & - & - & - & - & - & - & - & - & - \\
\hline Pyrophacus steinii (Schiller) Wall \& Dale & $\mathrm{x}$ & - & - & - & - & - & - & $\mathrm{x}$ & - & - & - & - & - & - & - & - & - & - & - \\
\hline SILICOFLAGELLATES & - & - & - & - & - & - & - & & - & - & - & - & - & - & - & - & - & - & - \\
\hline$\S$ Dictyocha cruz Ehrenberg & $\mathrm{x}$ & - & - & - & - & - & - & & - & - & - & - & - & - & - & - & - & - & - \\
\hline Dictyocha fibula Ehrenberg & $\mathrm{x}$ & - & - & - & - & - & - & $\mathrm{x}$ & & $\mathrm{x}$ & $\mathrm{x}$ & $\mathrm{x}$ & - & - & - & - & - & - & - \\
\hline Octactis octonaria (Ehrenberg) Hovasse & $\mathrm{x}$ & - & - & - & - & - & - & $\mathrm{x}$ & - & - & - & - & - & - & - & - & - & - & - \\
\hline COCCOLITHOPHORIDS & - & - & - & - & - & - & - & - & - & - & - & - & - & - & - & - & - & - & - \\
\hline Emiliania huxleyi (Lohmann) Hay \& Mohler & - & - & - & - & - & - & - & - & - & - & $\mathrm{x}$ & - & - & - & - & - & - & - & - \\
\hline Calciosolenia murrayi Gran & - & - & - & - & - & - & - & - & - & - & $\mathrm{x}$ & - & - & - & - & - & - & - & - \\
\hline Calciopappus caudatus Gaarder \& Ramsfjell & - & - & - & - & - & - & - & - & - & - & $\mathrm{x}$ & $\mathrm{x}$ & - & - & - & - & - & - & - \\
\hline $\begin{array}{l}\text { Umbilicosphaera sibogae (Weber-van Bosse) } \\
\text { Gaarder }\end{array}$ & - & - & - & - & - & - & - & - & - & - & - & $\mathrm{x}$ & - & - & - & - & - & - & - \\
\hline Ophiaster hydroideus (Lohmann) Lohmann & - & - & - & - & - & - & - & - & - & - & $\mathrm{x}$ & $\mathrm{x}$ & - & - & - & - & - & - & - \\
\hline EBRIIDEANS & - & - & - & - & - & - & - & - & - & - & & & - & - & - & - & - & - & - \\
\hline Ebria tripartita (Schumann) Lemmermann & $\mathrm{x}$ & - & - & - & - & - & - & - & - & $\mathrm{x}$ & & $\mathrm{x}$ & - & - & - & - & - & - & - \\
\hline$\S$ Hermesinum adriaticum Zacharias & $\mathrm{x}$ & - & - & - & - & - & - & - & - & - & - & - & - & - & - & - & - & - & - \\
\hline CYANOBACTERIA & - & - & - & - & - & - & - & - & - & - & - & - & - & - & - & - & - & - & - \\
\hline $\begin{array}{l}\S \text { Johannesbaptistia pellucida (Dickie) W.R. } \\
\text { Taylor \& Drouet }\end{array}$ & $\mathrm{x}$ & - & - & - & - & - & - & - & - & - & - & - & - & - & - & - & - & - & - \\
\hline $\begin{array}{l}\text { Trichodesmium erythraeum } \\
\text { Ehrenberg ex Gomont }\end{array}$ & $\mathrm{x}$ & - & - & - & - & - & - & - & - & - & - & - & $\mathrm{x}$ & & & & - & - & - \\
\hline $\begin{array}{l}\S \text { Trichodesmium thiebautii } \\
\text { Gomont ex Gomont }\end{array}$ & $\mathrm{x}$ & & & & & & & & & & & & & & & & - & - & - \\
\hline
\end{tabular}

Legend: *cited in $30-50 \%$ of publications; ** cited in 51-80\% of publications; $\uparrow$ nomenclature/taxonomy to be verified; $\S$ new record (present survey, 2004-2006).

Legenda: *citada em 30-50\% das publicações; ** citada em 51-80\% das publicações; $†$ nomenclatura/taxonomia exige verificação; $\S$ novo registro (levantamento atual, 2004-2006). 